\title{
Targeting Protein Kinase C in Glioblastoma Treatment
}

\author{
Noelia Geribaldi-Doldán ${ }^{1,2,+} \oplus$, Irati Hervás-Corpión ${ }^{2,3,+}$, Ricardo Gómez-Oliva ${ }^{2,4} \oplus$, Samuel Domínguez-García ${ }^{2,4}$,

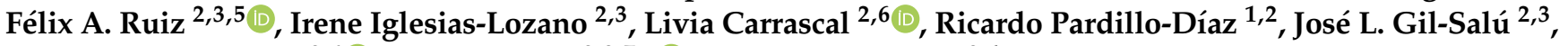 \\ Pedro Nunez-Abades ${ }^{2,6}\left(\mathbb{D}\right.$, Luis M. Valor $2,3,7, * \mathbb{C}$ and Carmen Castro ${ }^{2,4, *}$
}

1 Departamento de Anatomía y Embriología Humanas, Facultad de Medicina, Universidad de Cádiz, 11003 Cádiz, Spain; noelia.geribaldi@uca.es (N.G.-D.); ricardo.pardillo@uca.es (R.P.-D.)

2 Instituto de Investigación e Innovación Biomédica de Cádiz (INiBICA), 11009 Cádiz, Spain; ihervas91@gmail.com (I.H.-C.); ricardo.gomez@gm.uca.es (R.G.-O.); samuel.dominguez@uca.es (S.D.-G.); felix.ruiz@uca.es (F.A.R.); ilirene27@gmail.com (I.I.-L.); livia@us.es (L.C.); jlgilsalu@hotmail.com (J.L.G.-S.); pnunez@us.es (P.N.-A.)

3 Unidad de Investigación, Hospital Universitario Puerta del Mar de Cádiz, 11009 Cádiz, Spain

4 Área de Fisiología, Facultad de Medicina, Universidad de Cádiz, 11003 Cádiz, Spain

5 Área de Nutrición, Facultad de Medicina, Universidad de Cádiz, 11003 Cádiz, Spain

6 Departamento de Fisiología, Facultad de Farmacia, Universidad de Sevilla, 41012 Sevilla, Spain

7 Currently at Instituto de Investigación Sanitaria y Biomédica de Alicante (ISABIAL), 03010 Alicante, Spain

* Correspondence: valor_lui@externos.gva.es (L.M.V.); carmen.castro@uca.es (C.C.)

+ These authors contributed equally to this work.

\section{check for}

updates

Citation: Geribaldi-Doldán, N.; Hervás-Corpión, I.; Gómez-Oliva, R.; Domínguez-García, S.; Ruiz, F.A.; Iglesias-Lozano, I.; Carrascal, L.; Pardillo-Díaz, R.; Gil-Salú, J.L.; Nunez-Abades, P.; et al. Targeting Protein Kinase C in Glioblastoma Treatment. Biomedicines 2021, 9, 381. https://doi.org/10.3390/

biomedicines 9040381

Academic Editor: Sevin Turcan

Received: 22 February 2021

Accepted: 31 March 2021

Published: 4 April 2021

Publisher's Note: MDPI stays neutral with regard to jurisdictional claims in published maps and institutional affiliations.

Copyright: (c) 2021 by the authors. Licensee MDPI, Basel, Switzerland. This article is an open access article distributed under the terms and conditions of the Creative Commons Attribution (CC BY) license (https:/ / creativecommons.org/licenses/by/ $4.0 /)$.
Abstract: Glioblastoma (GBM) is the most frequent and aggressive primary brain tumor and is associated with a poor prognosis. Despite the use of combined treatment approaches, recurrence is almost inevitable and survival longer than 14 or 15 months after diagnosis is low. It is therefore necessary to identify new therapeutic targets to fight GBM progression and recurrence. Some publications have pointed out the role of glioma stem cells (GSCs) as the origin of GBM. These cells, with characteristics of neural stem cells (NSC) present in physiological neurogenic niches, have been proposed as being responsible for the high resistance of GBM to current treatments such as temozolomide (TMZ). The protein Kinase C (PKC) family members play an essential role in transducing signals related with cell cycle entrance, differentiation and apoptosis in NSC and participate in distinct signaling cascades that determine NSC and GSC dynamics. Thus, PKC could be a suitable druggable target to treat recurrent GBM. Clinical trials have tested the efficacy of PKC $\beta$ inhibitors, and preclinical studies have focused on other PKC isozymes. Here, we discuss the idea that other PKC isozymes may also be involved in GBM progression and that the development of a new generation of effective drugs should consider the balance between the activation of different PKC subtypes.

Keywords: glioblastoma; protein kinase C; glioma stem cells; neurogenesis; neural stem cells; temozolomide; enzastaurin; epidermal growth factor receptor; neuregulin

\section{Gliomas: Characteristics, Classification and Epidemiology}

Gliomas account for 30\% of all tumors of the central nervous system (CNS) and $80 \%$ of all malignant brain tumors in adults [1]. Although diffuse gliomas are considered as rare disorders, approximately 100,000 people worldwide are diagnosed with this pathology every year, with it being the second most common cancer in children and adolescents (26\% of all cancers) [2-4]. Glioma incidence varies with age, sex, ethnicity, tumor histology, and between populations around the world [5].

Based on histopathological criteria and malignancy grade, gliomas are classified as astrocytomas and oligodendrogliomas (OD), either diffuse (grade II) or anaplastic (grade III) and glioblastomas (GBM; grade IV). Briefly, histological features used in the clinical diagnosis of gliomas include: nuclear atypia (grade III), in addition to necrosis and microvascular changes (grade IV). In addition, these latter tumors exhibit high infiltrative and proliferative capacity and increased mitotic activity compared to grade II lesions [6]. This review 
focuses on GBMs as they are the most common ( $54 \%$ of all gliomas) and the most aggressive in adults, with a median overall survival (OS) of $\approx 15$ months. Additionally, GBM has a high incidence of recurrency $(>90 \%)$, despite intensive clinical management including surgery, radiotherapy and adjuvant chemotherapy. GBM can appear at any age but the peak incidence is between 75 to 84 years [7]. The incidence of these tumors is approximately $50 \%$ higher in males compared to females [8] and it differs substantially between ethnic groups, e.g., it is higher in Caucasians as compared to black populations [7,9,10]. As regards their location, they are most commonly situated in the supratentorial region (frontal, parietal, temporal and occipital lobes), with the highest incidence in the frontal lobe [11], while they are rarely located in the cerebellum [12]. Furthermore, the incidence of GBM increases in patients with hereditary tumor syndromes, such as Turcot syndrome [13] and Li-Fraumeni syndrome [14].

Since diagnosis and prognosis of gliomas based on histological features is insufficient, the 2016 World Health Organization Classification of Tumors of the Central Nervous System (2016 CNS WHO) incorporated molecular parameters to improve clinical interventions in patients with this pathology [15]. Amongst the molecular genetic alterations used to redefine glioma entities, the most common are mutations in the isocitrate dehydrogenase 1 and 2 (IDH1, IDH2) genes and the $1 \mathrm{p} / 19 \mathrm{q}$ co-deletion status [16-18]. According to the IDH condition, gliomas are divided into IDH-mutant (IDH1 R132 or IDH2 R172) and IDH-wild-type; 90\% of GBMs (usually primary or "de novo" GBMs) are wild-type for IDH and have a poor prognosis (median OS of 1.2 years). Meanwhile, secondary GBM $(10 \%)$ develops through progression from a low-grade lesion and is associated with a better prognosis and survival rate due to the IDH mutation (median OS of 3.6 years) [1,6,19-21]. This biomarker, used in combination with the loss of heterozygosity in chromosomal arms $1 \mathrm{p} / 19 \mathrm{q}$ for the diagnosis of grade II and III oligodendrogliomas, is linked to favorable clinical behaviors $[20,21]$. In the case of tumors which cannot be classified into any of these groups due to lacking sufficient pathological and genetic information (i.e., absence of appropriate diagnostic molecular testing or inconclusive results), the 2016 CNS WHO assigned the NOS (Not Otherwise Specified) category, which should be the subject to future studies $[15,16]$. Nonetheless, other biomarkers with predictive value of the progression and response to the first-front therapeutics are also frequently used in the clinic. The loss of ATRX (alpha thalassemia/mental retardation syndrome X-linked) is a recurrent marker of astrocytoma and secondary GBM and is associated with IDH and TP53 mutations, which are linked to a good outcome [22]. Hypermethylation of the MGMT $\left(\mathrm{O}^{6}\right.$-methylguanineDNA methyltransferase) promoter is considered an important predictor of a good response to chemotherapy with temozolomide (TMZ) in glioma patients $[23,24]$. Telomerase reverse transcriptase (TERT) promoter mutations have been detected in more than $50 \%$ of primary adult GBM and are correlated with increased telomerase activity [24,25], having been linked to lower survival times in GBM patients [26]. However, in combination with IDH1 and MGMT mutations, these mutations are good predictors of grade II and grade III gliomas [27]. Finally, EGFR (epidermal growth factor receptor) expression, without loss of PTEN (phosphatase and tensin homolog), explains the sensitivity of gliomas to tyrosine kinase inhibitors [28]. In conclusion, the use of molecular traits is assisting with the classification of gliomas, the high biological heterogeneity of which require the use of different experimental models for their study [29] and different strategies of clinical management.

\section{Neurogenesis and Glioblastoma}

Over recent years the concept of neurogenesis has evolved, from being considered a process constrained to embryonic stages, to now being considered relevant in adulthood [30]. Neurogenesis is defined as the process in which neural stem cells (NSCs) are activated and form new cells of a neural phenotype. NSCs can form neural progenitor cells (NPCs) that have a faster capacity of division as compared to NSCs. NPCs also have the potential to generate all the brain cell lineages, including neurons, astrocytes and oligodendrocytes [31-33]. Indeed, stem cell dynamics are determined by several signals that promote symmetric or asymmetric divisions, for either the maintenance of 
the stem cell pool or promotion of cellular differentiation. In further detail, symmetric auto-regenerative divisions expand the NSC population by generating two cells identical to the mother cell, whereas symmetric differentiated division generates two daughter cells that are different from the mother cell [34]. Asymmetric divisions render two cells, one identical to the mother cell and another more differentiated one. Neurogenesis occurs in different regions of the adult brain under physiological conditions, primarily—and also the most extensively explored-subventricular zone (SVZ) and the dentate gyrus (DG) of the hippocampus $[35,36]$. As opposed to mouse models, adult neurogenesis in the human DG is still a controversial issue. Some authors uphold that there is a continuous addition of new neurons in the DG [37], others support the idea that neurogenesis does not really occur in the adult human hippocampus [38-40]. In any case, ageing decreases the number of proliferating cells in the human SVZ [38]. The SVZ is located in the lateral walls of the brain ventricles and it is characterized by a specific architecture with a spatial arrangement of the neuroepithelium similar to the embryonic stage [41-43]. However, NSCs of the embryonic stage can continuously change their potentiality, in contrast to the adult state where NSC potentiality is relatively stable [41]. The NSCs of the SVZ (also called B1 type cells) have many characteristics that are typical of astrocytes $[36,44]$ but have the capacity to generate all neural cell lineages including neurons, astrocytes and oligodendrocytes. Quiescent $B 1$ cells can be activated and change their state to finally generate cells with a different grade of differentiation [36,45]. Via asymmetric division, these B1 cells can form C type cells (transit-amplifying cells) that have the capacity to form type A cells (neuroblasts) $[36,44,46]$. In humans, neuroblasts originating from the SVZ migrate to the striatum and not to the $\mathrm{OB}$ (olfactory bulb) as is the case in mice [47]. Both the persistence of B1 cells in the adult SVZ and their capacity to either be in quiescent or activated state, suggest that these cells may be the possible origin of malignant gliomas [48,49]. Furthermore, gliomas contain glioma stem cells (GSC) with characteristics that are similar to type B1 cells and have been postulated as the cells responsible for the origin of GBM and for the resistance of some malignant tumors to medical treatments. Different signaling pathways support or misfit the dynamics of the niche, which can be altered by the presence of mutations in the signaling molecule genes and receptors or by environmental factors that regulate their presence within the niche [50] (Figure 1).

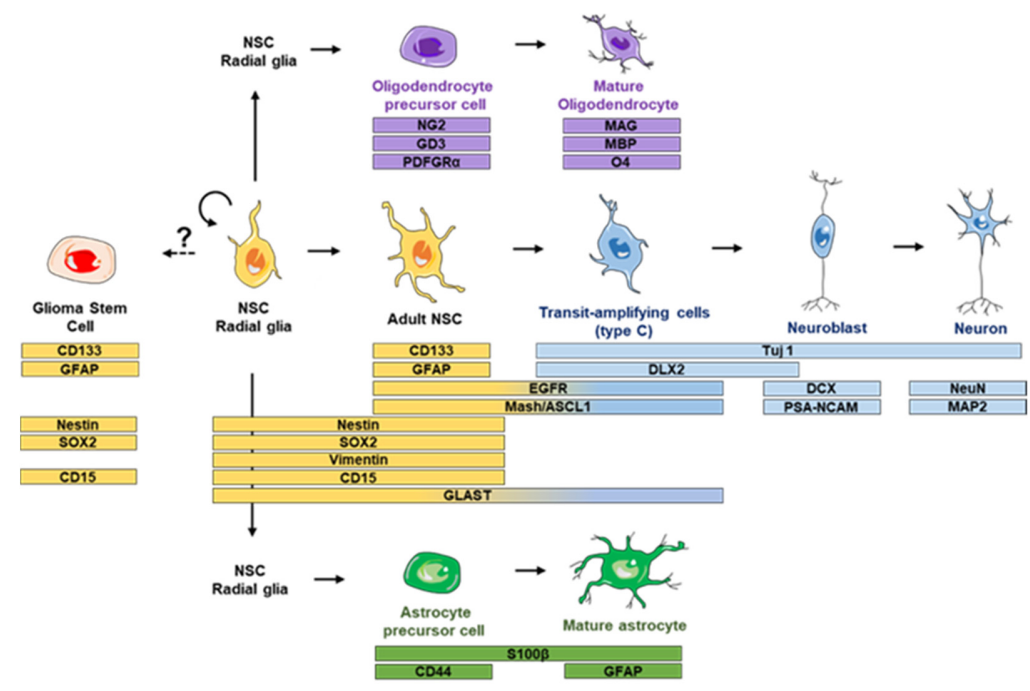

Figure 1. Markers of glioma stem cells, neural stem cells and their progeny. GFAP: glial fibrillary acidic protein; CD133: prominin 1; SOX2: sex determining region Y-box 2; NG2: neuron-glial antigen 2; GD3: GD3 ganglioside; PDGFRa: platelet derived growth factor receptor alpha; MAG: myelin associated glycoprotein; MBP: myelin basic protein; O4: surface antigen O4; GLAST: astrocytic glutamate transporter; EGFR: epidermal growth factor receptor; ASCL1: Achaete-scute complex homolog-1 (ASCL1), known as MASH1 in rodents; Tuj1: neuron-specific class III beta-tubulin; DLX2: distal-less homeobox 2; DCX: doublecortin; PSA-NCAM: polysyalated-neural cell adhesion molecule; NeuN: hexaribonucleotide binding protein-3; MAP2: microtubule associated protein 2. 


\section{The SVZ Cytoarchitecture as an Important Niche to Induce Glioblastoma}

As indicated above, the SVZ is located on the lateral border of the lateral ventricles and it constitutes one of the neurogenic niches that is preserved in adulthood. Around $50-60 \%$ of GBMs, which are associated with a short life expectancy, are linked to mutations in the cells of the SVZ, pointing to an association between both [51,52]. In fact, GBMs associated with the SVZ are most likely to be multifocal at diagnosis, recur at great distances from the initial lesion/s, and exhibit a transformation from NSC to GSC [53]. Not only the characteristic neuroepithelium tissue is responsible for the proliferation and differentiation capacity of this brain region, but the vascular architecture is also intimately related with the development of GBM. In the SVZ, NSCs are located close to the blood vessels, which in turn, are essential for their maintenance and survival [54-56]. In cancer, vascularization is essential for understanding tumor growth and metastasis, and therefore, it has a direct relationship with malignancy. This is of special interest, as GBM is one of the most malignant and vascularized types of brain tumor [57]. Indeed, GSCs interact with the vasculature, and specifically, with pericytes within the niche $[58,59]$ and are able to transdifferentiate into endothelial cells (EC) in order to contribute to their own vasculature. All these connections establish a specific niche that contributes to creating a microenvironment that promotes proliferation [60-62]. In addition, it is important to highlight that the human SVZ can be separated into four layers, the ependymal layer (I), the hypocellular layer (II), the astrocytic ribbon layer (III) and the transitional layer (IV); between the ependymal layer and the neurogenic astrocytes, there exists a hypocellular gap [63-65] that is related with proliferation of NSC. Within the SVZ niches, the oxygen concentration can determine cell survival and stemness in NSC and GSC [66,67]. In GBM, hypoxia favors GSC self-renewal and it also induces the secretion of several factors, such as TGF $\beta$, that promotes angiogenesis via vascular endothelial growth factor (VEGF) or stroma cell-derived factor 1 (SDF-1) [68,69].

\section{Glioma Stem Cells and Neural Stem Cells}

In addition to NSCs, GSCs have been isolated and cultivated in vitro. Their characterization has revealed similarities between both types of cells, including self-renewal, proliferation capacity and differentiation. One of the most important points that they have in common is the expression of several markers, such as nestin [70] (Figure 1). This intermediate filament protein is characteristic of stem cells and progenitor cells, and is expressed during embryonic development and in adult undifferentiated cells [31]. Additionally, expression of nestin in tumor cells is correlated with the malignancy of the tumor [71] and with the cell capacity to form spherical aggregates, commonly called neurospheres or, more precisely, tumorospheres or oncospheres [72]. Neurosphere assays have been crucial in finding similarities between NSC and GSC properties [73-75], such as the capability to be passaged several times and to be cultured under differentiation conditions. Moreover, GSCs that are capable of forming tumorospheres allow in vivo studies of tumorigenesis as they are able to initiate a new tumor in xenotransplanted nude mice [74].

Another shared marker between both types of stem cells is CD133, also called prominin. CD133 is a membrane bound glycoprotein with a crucial function in cell differentiation, proliferation and in epithelial to mesenchymal transition [76]. Most CD133 ${ }^{+}$cells have the capacity to form tumorospheres and are present in a small subpopulation of cells in brain tumors [77]. This marker is also related to the clonal capacity of these kind of cells. Lastly, $\mathrm{CD} 133^{+}$cells have a high level of telomerase activity that is correlated with neural stem cell abilities [78,79]. Despite this, the use of CD133 as a marker of tumorigenesis has been recently challenged because of the discovery of differentiated cells expressing CD133 and the capacity to initiate tumors in some CD133- cells $[76,80]$.

Other molecular markers are involved in molecular pathways that determine proliferation, differentiation or migration, such as the EGFR, which can be amplified to form up to 10 additional copies in GBM [76,81]. Other markers present in GSC are CD15, characteristic of the embryonic stage and also present in NSC [82,83], L1CAM which is critical to the 
adhesion process in growth and migration in CNS development and also in the survival of CD133 ${ }^{+}$GSCs [84], and several transcriptional factors (e.g., Sox2, Olig2, Nanog, c-Myc) that can be used in the identification of GSCs and are important for their survival [85] (Figure 1).

Although NSCs and GSCs share multiple similarities, there are also crucial differences that are based on the capacity of invasion and the immune response characteristics of GSC, that are not present in NSCs [86], and are key in glioma research. The use and identification of appropriate markers forms the basis to clarify the similarities and differences between GSC and NSC in the research of new therapeutic targets that could help the development of effective treatments.

\section{Active Signaling Pathways Involved in Proliferation, Tumor Growth and Invasion in GBM}

The study of GBM-related pathways is critical in developing new therapeutic drugs. The tyrosine kinase pathways involve the tyrosin kinase receptors (RTKs). RTKs are receptors for several ligands, such as hormones, growth factors, and cytokines, that initiate either the Ras small GTPase/mitogen activated kinase (Ras/ERK) or the Ras/Phosphoinositide 3-kinase-Akt (Ras/PI3K-Akt) pathways, both related to proliferation and survival but also to differentiation [87]. The aforementioned EGFR is among the most relevant RTKs and is involved in proliferation, related to the high resistance to treatments $[24,88,89]$. Other relevant RTKs include VEGFR, tightly linked with angiogenesis and hypoxia [90]; fibroblast growth factor receptor (FGFR), which plays a role in tumorigenesis and is used to increase proliferation in vitro [91,92]; platelet-derived growth factor receptor(PDGFR); hepatocyte growth factor receptor/mesenchymal-epithelial transition factor (HGFR/c-MET), involved in the development of several types of cancer including GBM $[93,94]$. As a control mechanism of these pathways, PTEN functions as a tumor suppressor by negatively regulating protein kinase signaling cascades which are implicated in tumorigenesis. Due to its dual phosphatase activity, PTEN inhibits the PI3K/AKT/mTOR pathway by dephosphorylating either phosphatidylinositol or the downstream phosphorylated substrates of this pathway. Loss of PTEN is frequent in GBM [95], in which the activity of the PI3K-AKT pathway increases proliferation and facilitates migration. However, PTEN-deficient GBM depend differently on the two PI3K isoforms, p110a and p110b for proliferation and migration, respectively [96].

Protein kinase C (PKC) is key in understanding the cell proliferation, differentiation, survival and migration processes mediated by these pathways in the normal brain and also in pathogenic conditions [97], as we will discuss in the following sections.

\section{Protein Kinase C: Characteristics, Structure, Classification and Activating Molecules}

The PKC family includes serine-threonine kinases that catalyze the phosphorylation of a huge variety of substrates which are important in several biological processes, such as cell cycle entry, apoptosis, proliferation, and differentiation, among other basic functions [98-100]. Under normal conditions, PKC activation requires the binding of regulators, such as diacylglycerol (DAG), calcium and phosphatidyl serine (PS). Depending on their regulatory domains and their basic activators, 10 different PKC isozymes have been described that are classified in three subfamilies [101]: classical, novel and atypical PKCs (See Figure 2). Classical PKCs $(\alpha, \beta$, and $\gamma)$ use calcium, DAG and PS for their activation, while novel PKCs $(\delta, \varepsilon, \theta$, and $\eta)$ are also activated by DAG and PS but are calcium independent. Atypical PKCs $(\lambda / \mathrm{J}$ and $\zeta$ ) are regulated by protein-protein interactions [102]. All PKCs contain a C-terminal kinase domain and an N-terminal regulatory domain. The N-terminal regulatory domain of both classical and novel PKCs contains a $\mathrm{C} 1$ domain that is divided into $\mathrm{C} 1 \mathrm{~A}$ and $\mathrm{C} 1 \mathrm{~B}$ subdomains and a $\mathrm{C} 2$ domain. In the case of classical PKC, the $\mathrm{C} 2$ domain and $\mathrm{C} 1$ domain are adjacent and bind $\mathrm{Ca}^{+}$and $\mathrm{DAG}$, respectively. In contrast, the $\mathrm{C} 2$ domain of novel PKC does not respond to $\mathrm{Ca}_{2}{ }^{+}$, therefore, these enzymes are DAG-sensitive and Ca2 ${ }^{+}$-independent [101,103-106]. Atypical PKCs lack the 
C2 domain but contain a C1 domain, which does not respond to DAG. Atypical PKCs contain a PB1 domain that binds PB1 binding proteins, which have scaffolding functions.

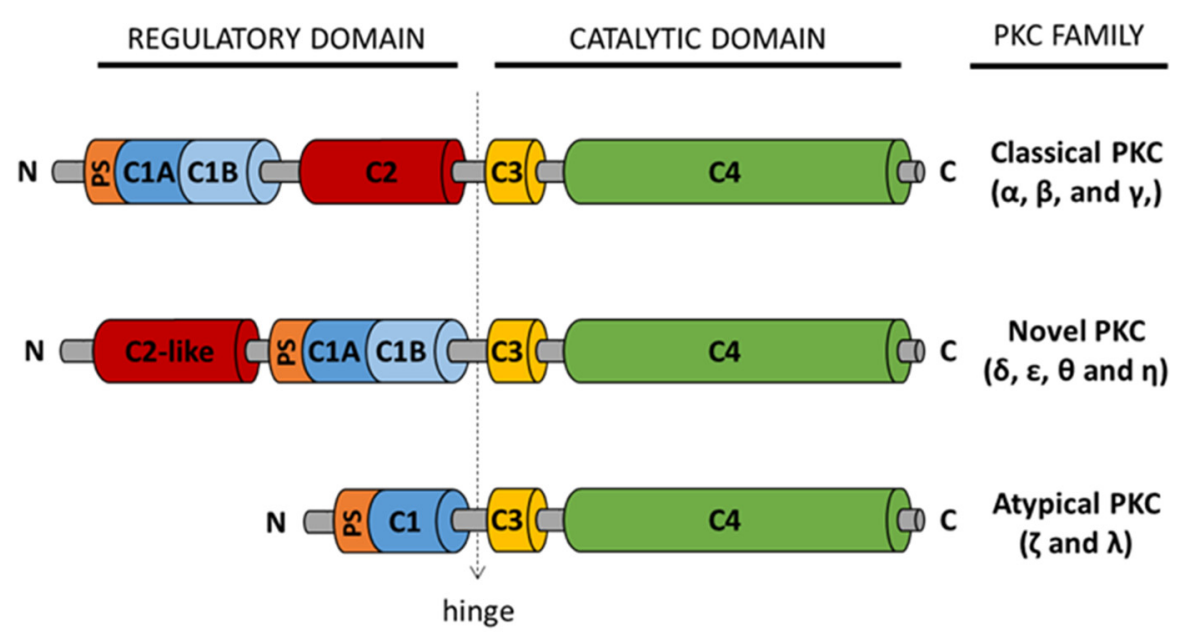

Figure 2. Classification and structure of PKC isozymes. Regulatory domains (C1A, C1B and C2) and binding sites for regulatory molecules: diacylglycerol (DAG), Ca2+, and phosphatidyl Serine (PS), as well as the conserved catalytic domains (C3 and C4) are shown.

As indicated above, the physiological molecule that activates classical and novel PKC in cells is DAG that, once synthesized in a reaction catalyzed by phospholipase $C$, binds to the $\mathrm{C} 1$ domain of classical and novel PKC. Chemical compounds with molecular structures similar to DAG have been widely used as PKC activating molecules in research. The best known is phorbol myristate acetate (PMA), which irreversibly activates PKC, translocating it to the plasma membrane, but also mediates its ubiquitination and degradation, as we will explain below. PMA has been described as tumorigenic in most tissues [107], although the mechanism underlying such tumorigenic effect is still a matter of debate.

Other PKC activating compounds have been described with a chemical structure similar to that of PMA. This is the case of prostratin, a diterpene with a 12-deoxyphorbol structure isolated from the Samoan plant Homolantus nutans. Prostratin has been described as a non-tumor promoting compound with the capability to activate classical and novel PKC, without showing carcinogenic properties [108]. Similar phorbol derived diterpenes with a tigliane or lathyrane skeleton have been described with similar PKC activating properties that also promote NSC proliferation [109,110]. Additionally, semi-synthetic prostratin-like epoxytiglianes have proven to be efficacious against established tumors in mice [111]. Thus, a great variety of compounds that are able to target specific PKC isozymes are now available.

PKC activation has been proven to be crucial for NSC proliferation and differentiation, although not all isoenzymes behave identically during these processes [97]. For example, the proliferation of NSCs isolated from the SVZ of induced adult mice is stimulated with classical PKC activating diterpenes with a 12-deoxyphorbols or lathyrane structure $[109,110,112]$. This facilitates the ADAM17-mediated release of EGFR ligands such as TGF $\alpha$ [113] and activates the PI3K-AKT and MAPK pathways [114], in addition to also activating cyclin D1 expression [109]. On the contrary, PKC inhibition facilitates the differentiation of NSCs towards a neuronal phenotype, reducing their proliferation rate [115].

In contrast, specific activation of novel PKCs with diterpenes with a lathyrane structure, such as EOF2, promotes differentiation towards a neuronal phenotype, reducing proliferation by facilitating the ADAM17-mediated release of neuregulin. The selectivity of ADAM17 for EGFR ligands, or for neuregulins, depends on the phosphorylation reactions that take place in the cytosolic domain of the membrane-bound pro-TGF $\alpha$ or pro-neuregulin molecules. These reactions are catalyzed by kinases of the PKC family [116]. 
In particular, activating PKC $\alpha$ by PMA results in the phosphorylation of TGF $\alpha$, amphiregulin and Heparin binding EGF-like growth factor (HB-EGF) membrane-bound pro-ligands enabling their shedding mediated by ADAM17 and releasing the soluble domain of the growth factor to the extracellular space [116]. On the contrary, activation of the novel PKC $\delta$ enables ADAM17-mediated NRG1 ectodomain shedding. The scission of the ectodomain is enabled by the phosphorylation of serine 286 in the intracellular domain of NRG1, which is catalyzed by PKC $\delta[98,117]$. Taken together, this evidence indicates that ADAM17 substrate specificity and selectivity depends on the activation of different PKC isozymes in order to exert its crucial role on the secretion of different neurotrophic factors [116,117] which are necessary for governing NSC physiology.

\section{Protein Kinase $\mathrm{C}$ and Glioblastoma}

In contrast to the usual actions of PKCs in different cancer cell types, their role in the development of GBM seems to be different depending on the isozyme [118]. Below, we analyze the different PKC isozymes to understand their implication in the development of GBM and their potential as targets for GBM treatments. Figure 3 contains a summary of the activities of different PKC isozymes in GBM physiology.

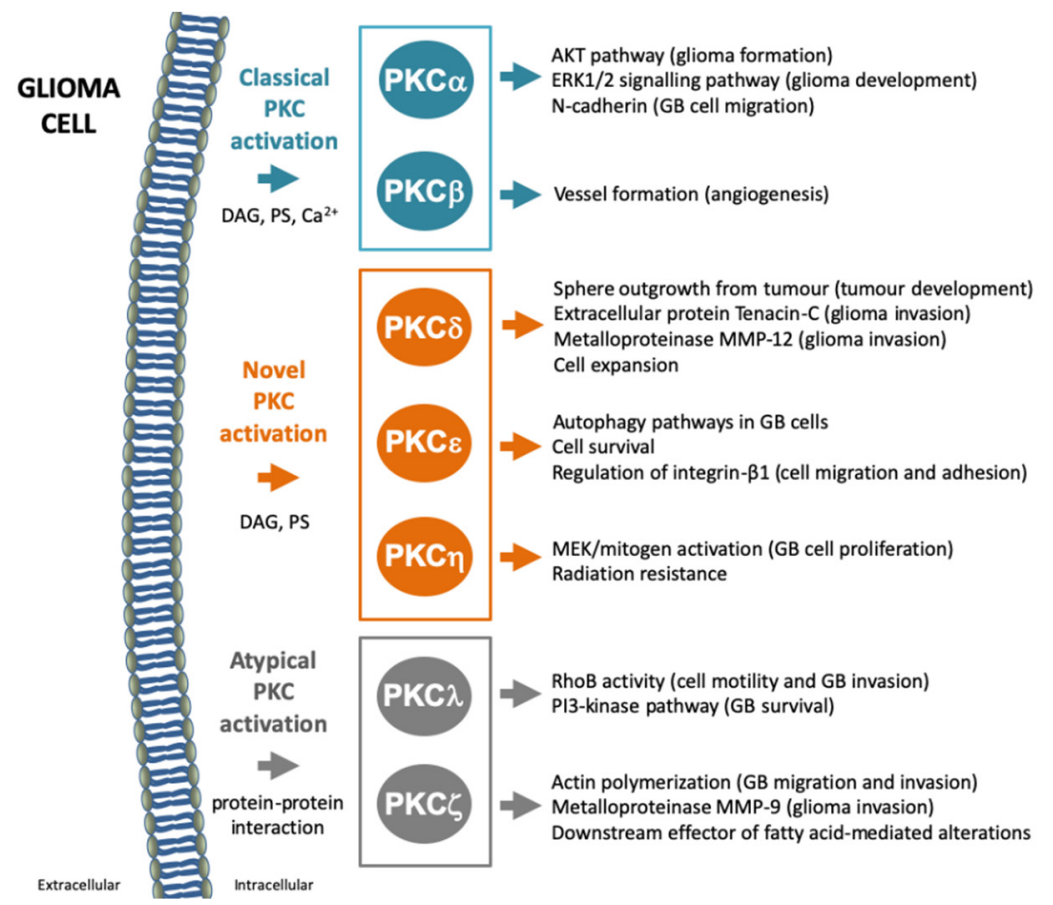

Figure 3. Effect of classical, novel and atypical protein kinase $\mathrm{C}$ (PKC) activation in glioblastoma (GBM) physiology. Figure highlights the effects of activating different PKC isozymes in GBM.

\section{1. $P K C \alpha$}

Several studies have shown that PKC $\alpha$ plays a role in GBM cell survival and proliferation, as well as in promoting invasion. Inhibiting PKC $\alpha$ activity may result in GBM, along with reductions in cell growth, survival, migration and invasion. Thus, PKC $\alpha$ seems to have a specific function in glioma formation because it is required for the activation of several pathways. For example, PKC $\alpha$ links the EGFR and mTORC1 pathways, independent of the AKT pathway [119], which participates in glioma viability. This suggests that inhibition of PKC $\propto$ may lead to a reduction in the viability of glioma cells. More recently, a decrease in GBM cell proliferation and induced apoptosis caused by the cooperative inhibition of Janus kinase 2 (JAK2) and PKC $\alpha$ has been demonstrated [120]. Moreover, the basic fibroblast growth factor (bFGF) is one of the principal mitogens in glioma development, which is linked to the ERK1/2 signaling pathway, activated by PKC $\alpha$ [121]. PKC $\alpha$ is indirectly related to migration and invasion, specifically because of its role in the ADAM10 mediated 
release of the adhesion molecule, $\mathrm{N}$-cadherin. PKC $\alpha$ inhibitors seem to significantly reduce GBM cell migration [122]. Another pathway involved in GBM growth is the LPA1-induced translocation of PKC $\alpha$ to the cell nucleus, as blocking this pathway leads to a reduction in cell proliferation in GBM [123]. All these reports suggest a role for classical PKC $\alpha$ in GBM tumorigenesis, indicating that the regulation of PKC $\alpha$ activity can be targeted as a potential treatment of GBM.

\section{2. $P K C \beta$}

This PKC isozyme seems to have opposite roles in GBM. It has long been considered to play a role in the induction of angiogenesis, facilitating tumor progression. Thus, targeting PKC $\beta$ in GBM treatment has been long pursued in preclinical and clinical studies. Considering that angiogenesis is essential for GBM development, $\mathrm{PKC} \beta$ may play a direct role in tumor establishment and progression because of its role as a key molecule in vessels formation [124]. The most promising therapeutic approach using PKC $\beta$ as a target molecule came from the use of a specific inhibitor called enzastaurin (LY317615), that directly affected the proliferation capacity of cells. Specifically, this inhibitor suppressed the AKT signaling pathway, inducing tumoral cell death and suppressing tumor growth and angiogenesis at the same time [125]. Despite these promising results, phase III clinical studies in recurrent GBM have not demonstrated a better efficiency of enzastaurin in comparison with other existing pharmacological agents, such as lomustine, an extensively used oral treatment [126]. On the contrary, a report from Liu et al. assigned an indirect role for PKC $\beta$ II activation as an inhibitor of GBM tumor growth, as it prolongs survival of a mouse orthotopic xenografts model and induction of apoptosis through inhibition of YAP/TAZ proteins of the hippo pathway $[127,128]$. Thus, two opposite roles for PKC $\beta$ have been described: a direct role on angiogenesis and tumor progression; an indirect role in detaining tumor growth and increasing survival.

\section{3. $P K C \delta$}

PKC $\delta$ has been reported to play a key role in several cellular functions within tumors, such as proliferation and survival. Chen et al. demonstrated that PKC $\delta$ depletion prevents sphere outgrowth from tumor cell cultures as well as the tumor development in xenograft models [129]. Other studies have reported that the reduction in PKC $\delta$ affects glioma invasiveness through its relationship with the regulation of the extracellular matrix components; indeed, the interference of PKC $\delta$ expression reduced the release or extracellular levels of the protein tenascin- $C$, resulting in the downregulation of matrix metalloprotease MMP-12, a metalloprotease required for cell migration and involved in tumor invasion [130]. Additional studies have discovered a role of PKC $\delta$ in increases in glioma-initiating cell populations, and in the reduction in cellular sensitivity to cancer treatments [131]. In addition, activation of PKC $\delta$ in glioma cells activates glycerol-3-phosphate dehydrogenase (GPDH), an essential enzyme in several glioma cell functions due to its basic functions in glycolysis, respiration and phospholipid biosynthesis. Additionally, phosphorylation of GPDH at threonine 10 correlates with the levels of p-PKC $\delta$ in human GBM and with the local number of macrophages within the zone releasing IL- $1 \beta$, which negatively affects tumor grade and patient survival [132], depicting a role for PKC $\delta$ in GBM growth and progression.

\section{4. $P K C \varepsilon$}

Novel PKC $\varepsilon$ has been related with several cell processes including cell survival and apoptosis. In GBM, PKC $\varepsilon$ is overexpressed in cell cultures [133]. Glioma cells treated with TRAIL (TNF-related apoptosis-inducing ligand), while also subjected to silencing $\mathrm{PKC} \varepsilon$ expression, undergo apoptosis, suggesting that this kinase is required for GSC survival [134]. Other authors have emphasized that the loss of PKC $\varepsilon$ contributes to the downregulation of genes related to autophagy pathways in GBM cells [135]. In addition, PKC $\varepsilon$ activates ERK, specifically at focal adhesions, in order to mediate integrin-dependent 
glioma cell adhesion and motility $[136,137]$. This plays a role in the regulation of the recycling of endocytosed integrin- $\beta 1$ to facilitate its return to the plasma membrane [138].

\section{5. $P K C \eta$}

Novel PKC $\eta$ plays important roles in cell proliferation, differentiation and cell death [139-141]. Using glioma-derived cell lines, AKT and mTOR were identified as the downstream targets of PKC $\eta$ in GBM [142]. Conversely, other authors propose that PKC $\eta$ induces GBM cell proliferation via ERK and ERK1 phosphorylation, involving $\mathrm{MEK} /$ mitogen activation [143]. Additionally, PKC $\eta$ has been related to the resistance to UV and gamma radiation by blocking the apoptotic cascade via caspase-9 activation [144].

\section{6. $P K C \lambda / \iota$}

Atypical PKC $\lambda /\llcorner$ is also involved in regulating the biology of GBM cells, particularly in terms of survival and cell migration. PKC $\lambda$ depletion produces an increase in RhoB activity, inhibiting cell motility and invasion in GBM cells [145]. In addition, PKC $\lambda$ promotes GBM cell survival by regulating the pro-apoptotic protein, Bad, via the PI3-kinase pathway [146]. A recent study, in which atypical PKC $\mathrm{t}$ and $\mathrm{PKC} \zeta$ inhibitors (ICA and $\zeta$ Stat, respectively) were tested in combination with TMZ in vitro in the U87MG cell line, showed an induction of apoptosis and a reduction in cell migration. However, the use of these inhibitors in mice transplanted with U87MG cells did not show a higher reduction in tumor volume in mice treated with ICA vs. TMZ [147].

\section{7. $P K C \zeta$}

The atypical PKC $\zeta$ has been proposed as a tumor suppressor because its depletion increases tumorigenesis in several types of cancers including GBM [148]. Additionally, $\mathrm{PKC} \zeta$ is postulated as a potential downstream effector of fatty acid-mediated alterations in GBM growth and migration [149]. Indeed, some authors associate PKC $\zeta$ with migration: silencing of PKC $\zeta$ impairs the phosphorylation of LIN-11, IsI1 and MEC-3 protein domain kinase (LIMK), which is important for actin polymerization, affecting migration and invasion in GBM [150]. Additionally, PKC $\zeta$ is related to NF- $\mathrm{kB}$ function in the signaling pathways dependent on MMP-9, a key metallopeptidase in tumor invasion [151]. A recent study demonstrated that inhibitors of this kinase, combined with TMZ, notably reduced the cell viability of GBM-derived cell lines [147].

\section{General Concerns on Conventional and Targeted Therapies in Glioblastoma}

The standard treatment of newly diagnosed GBs follows the Stupp protocol, that consists of the maximal surgical resection of the tumor, accompanied by a regimen of radiotherapy and temozolomide (TMZ) administration, aimed at the unspecific damage of the DNA in highly proliferative cells as a means to trigger their death. TMZ acts as an adjuvant alkylating agent of the ionized radiation by methylating the DNA, which most often occurs at the N-7 and O-6 positions of guanine residues, and N-3 positions of alanine residues [152]. Inclusion of TMZ leads to an increase in the OS by 2.5 months and reducing the mortality rate by $37 \%$ [153]. However, $>90 \%$ of the cases relapse with gliomas that are more aggressive and resistant to this treatment. Second-line treatment chemotherapy mainly consists of nitrosourea-based DNA alkylating agents such as CCNU (lomustine), BCNU (carmustine), ACNU (nimustine), or fotemustine, the type II topoisomerase inhibitor mitoxantrone and the monoclonal antibody against VEGF bevacizumab. Overall, followups of patient cohorts have reported a significant increase in OS and progression-free survival (PFS) of these patients over the last 10 years but these intensive efforts are still far for a complete cure.

In light of the different driver mutations found in GBM, several trials have aimed at developing targeted therapies directed against specific RTKs, such as EGFR, PDGFR, FGFR or VDGFR and their associated signaling pathways [154]. However, although some of them have provided interesting results, most clinical trials have not gone beyond phase III [155]. 
Intra-Tumor Heterogeneity and Tumor Microenvironment: Two Obstacles for Targeted Therapies

One of the factors mediating resistance to conventional and targeted therapies is the intra-tumor heterogeneity and plasticity of GBM. GBM harbors different cell types with somatic mutations that may confer different sensitivity to treatments. Therefore, resistance to therapy is not homogeneous within the tumor and depends on the molecular signatures of specific cells [156]. It is most likely that current therapeutic approaches only eliminate the sensitive tumor cell fraction, whereas the other cell sub-populations remain intact and result in relapse [155].

The tumor microenvironment influences this tumor evolutionary process and contributes to intra-tumor heterogeneity. Non-GSCs within the tumor, such as tumor-associated macrophages and microglial cells, contribute to generating this microenvironment. These immune cells-that account for almost $50 \%$ of the tumor mass-secrete factors that create a continuously evolving environment, together with hypoxia and availability of nutrients. Thus, interactions between cancer cells and the fluctuating tumor microenvironment modifies epigenetic regulation and gene expression, affecting its heterogeneity and constant evolution [156].

Identifying the key drivers of alterations in genes and their expression across different cell types is crucial in the development of therapeutic approaches that modify intra-tumor evolution and change drug resistance patterns for successful therapies.

\section{Clinical Trials Using PKC Targeting Drugs}

Several clinical trials conducted over the past 20 years have tested the effects of PKC inhibitors in GBM, mainly classical PKC inhibitors in the treatment of recurrent GBM. Treatment of relapsing patients is still challenging, as current clinical management involves surgery, radiotherapy and TMZ treatment with no better outcomes having been found by using alternative drugs (reviewed in Finch et al., 2021 [156]).

The first clinical trials using PKC targeting drugs tested the efficacy of tamoxifen. This nonsteroidal agent with high lipid solubility is able to cross the blood-brain barrier (BBB) and reach the tumor. Tamoxifen elicits the association of PKC to the membrane, followed by an irreversible activation, and subsequent down-regulation of the enzyme, leading to cell growth inhibition [157], cellular apoptosis, and at high doses, chemoresistance reversion $[158,159]$. For the treatment of GBM, Couldwell and colleagues and Brandes and colleagues were the first to use high-doses of tamoxifen to inhibit PKC, based on in vitro assays that evaluated apoptosis in GBM cells either alone, or in combination with procarbazine in phase II clinical trials. The most relevant finding was an increase in radiosensitivity $[160,161]$. However, the OS rates shown in these studies were 6.8 and 7.2 months, and the time to progression was 3.3 months. More promising results were observed in a more recent study in which tamoxifen was tested in combination with TMZ. In this study the observed median time to progression was 9.5 months and the OS was 17.5 months [162]. Additional clinical trials have tested tamoxifen in combination with other agents such as procarbazine or TMZ to affect PKC functionality and other targets [163-165] (see Table 1 for further details). 
Table 1. Summary of protein kinase C-related clinical trials for the treatment of glioblastoma.

\begin{tabular}{|c|c|c|c|c|c|c|c|}
\hline & Target & Authors and Year & Trial Phase & $\mathrm{N}^{\circ}$ Patients & Dose & PFS & OS \\
\hline Tamoxifen & PKC & Couldwell et al 1996 [160] & Phase II trial & 32 & $\begin{array}{l}200 \mathrm{mg} / \text { day ( } 100 \mathrm{mg} \text { twice daily) of tamoxifen was } \\
\text { administered to males } 160 \mathrm{mg} / \text { day ( } 80 \mathrm{mg} \text { twice daily) of } \\
\text { tamoxifen was administered to females }\end{array}$ & n.d. & 7.2 months \\
\hline $\begin{array}{l}\text { Tamoxifen }+ \\
\text { Procarbazine }\end{array}$ & PKC + DNA & Brandes et al 1999 [164] & Phase II trial & 53 & $\begin{array}{l}100 \mathrm{mg} / \text { day of tamoxifen }+100 \mathrm{mg} / \mathrm{m}^{2} / \text { day of } \\
\text { procarbazine were administered for } 30 \text { days with 30-day } \\
\text { intervals between cycles }\end{array}$ & 3 months (median) & 6.2 months \\
\hline \multirow[t]{2}{*}{ Tamoxifen + TMZ } & $\mathrm{PKC}+\mathrm{DNA}$ & $\begin{array}{l}\text { Spence et al. } 2004 \text { [165], } \\
\text { Cristofori et al. } 2013 \text { [162] }\end{array}$ & Phase II trial & 16 & $\begin{array}{c}40 \mathrm{mg} \text { twice daily of tamoxifen for } 1 \text { week and was } \\
\text { escalated to } 60 \mathrm{mg}, 80 \mathrm{mg} \text { then } 100 \mathrm{mg}+75 \mathrm{mg} / \mathrm{m}^{2} / \text { day } \\
\text { of TMZ for } 6 \text { weeks, repeated every } 10 \text { weeks, with a } \\
\text { maximum of } 5 \text { cycles }\end{array}$ & n.d. & 6 months \\
\hline & $\mathrm{PKC}+\mathrm{DNA}$ & Cristofori et al. 2013 [162] & Phase II trial & 32 & $\begin{array}{l}80 \mathrm{mg} / \mathrm{m}^{2} / \text { day of tamoxifen }+75-150 \mathrm{mg} / \mathrm{m}^{2} / \text { day of } \\
\text { TMZ was administered for one week on/one week off }\end{array}$ & $\begin{array}{l}9.5 \text { months } \\
\text { (median) }\end{array}$ & 17.5 months \\
\hline $\begin{array}{l}\text { Tamoxifen + } \\
\text { Radiation }\end{array}$ & PKC & Robins et al. 2006 [161] & Phase II trial & 75 & $\begin{array}{l}80 \mathrm{mg} / \mathrm{m}^{2} / \text { day of tamoxifen, divided in } 4 \text { doses of } \\
20 \mathrm{mg} / \mathrm{m}^{2} \text { every } 6 \mathrm{~h} \text {, was administered during and after } \\
\text { of } 60 \text { Gy in } 30 \text { fractions } \times 2 \text { Gy of radiotherapy } \\
800 \mathrm{mg} / \text { day of enzastaurin and } 400 \mathrm{mg} \text { twice daily and }\end{array}$ & $\begin{array}{l}2.9 \text { months } \\
\text { (median) }\end{array}$ & 11.3 months \\
\hline Enzastaurin & PKC $\beta$ & $\begin{array}{l}\text { Kreisl et al. } 2009 \text { [166] } \\
\text { Kreisl et al. } 2010[167]\end{array}$ & $\begin{array}{l}\text { Phase I trialPhase } \\
\text { I/II trial }\end{array}$ & $\begin{array}{l}2215 \text { (Phase I) } 103 \\
\quad \text { (Phase II) }\end{array}$ & $\begin{array}{l}500 \mathrm{mg} \text { /day and } 250 \mathrm{mg} \text { twice daily for patients not } \\
\text { taking EIAEDs and } 1000 \mathrm{mg} / \text { day and } 500 \mathrm{mg} \text { twice daily } \\
\text { for patients taking EIAEDs in phase I, patients who were } \\
\text { taking EIAEDs, received } 525,700 \text { and } 900 \mathrm{mg} / \text { day of } \\
\text { enzastaurin and patients in phase II, who were not taking } \\
\text { EIAEDs, received } 500 \text { or } 525 \mathrm{mg} / \text { day of enzastaurin }\end{array}$ & $\begin{array}{l}1.4 \text { months } \\
\text { (median) } \\
1.3 \text { months (median) } \\
7 \% \text { (at 6-month) }\end{array}$ & $\begin{array}{l}5.7 \text { months } \\
4.6 \text { months }\end{array}$ \\
\hline $\begin{array}{l}\text { Enzastaurin vs. } \\
\text { Lomustine }\end{array}$ & $\begin{array}{l}\text { PKC } \beta \text { vs. } \\
\text { DNA/Stathmin-4 }\end{array}$ & Wick et al. 2010 [126] & Phase III trial & 266 & $\begin{array}{l}500 \mathrm{mg} / \text { day of enzastaurin vs. } 100 \text { to } 130 \mathrm{mg} / \mathrm{m}^{2} \text { of } \\
\text { lomustine on day } 1 \text { with cycles of } 6 \text { weeks }\end{array}$ & $\begin{array}{c}\text { Enzastaurin: } \\
1.5 \text { months, } 11.1 \% \\
\text { (median, } \\
\text { at 6-month); } \\
\text { Lomustine: } \\
1.6 \text { months, } 19 \% \\
\text { (median, } \\
\text { at } 6 \text {-month) }\end{array}$ & $\begin{array}{l}\text { Enzastaurin: } \\
6.6 \text { months } \\
\text { Lomustine: } \\
7.1 \text { months }\end{array}$ \\
\hline $\begin{array}{l}\text { Enzastaurin }+ \\
\quad \text { TMZ }\end{array}$ & PKC $\beta+$ DNA & Rampling et al. 2012 [168] & Phase I trial & 28 & $\begin{array}{c}250 \mathrm{mg} / \text { day (once daily); } 500 \mathrm{mg} / \text { day (once daily); } \\
500 \mathrm{mg} / \text { day (250 mg twice daily) of enzastaurine. } \\
150-200 \mathrm{mg} / \mathrm{m}^{2} \mathrm{TMZ}\end{array}$ & $\begin{array}{l}5.5 \text { months } \\
\text { (median) }\end{array}$ & 11.7 months \\
\hline $\begin{array}{l}\text { Enzastaurin + } \\
\text { TMZ with } \\
\text { radiation }\end{array}$ & $\mathrm{PKC} \beta+\mathrm{DNA}$ & Butowski et al. 2010 [169] & Phase I trial & 12 & $\begin{array}{c}\text { Radiation therapy } 1.8-2.0 \mathrm{~Gy} \times 30 \text { fractions } 5 \text { days a } \\
\text { week for } 6 \text { weeks }+ \text { Enzastaurin } 250-500 \mathrm{mg} / \text { daily }+ \\
\text { TMZ } 75 \mathrm{mg} / \mathrm{m}^{2}\end{array}$ & n.d. & n.d. \\
\hline $\begin{array}{l}\text { Enzastaurin }+ \\
\text { Bevazizumab }\end{array}$ & PKC $\beta+$ VEGF & Odia et al. 2016 [170] & Phase II trial & 40 & $\begin{array}{c}\text { Enzastaurin } 500 \text { or } 875 \mathrm{mg} / \text { day + bevacizumab } \\
10 \mathrm{mg} / \mathrm{kg} \text { intravenously biweekly }\end{array}$ & 2.0 months & 7.5 months \\
\hline Aprinocarsen & PKC $\alpha$ & Grossman et al. 2005 [171] & Phase II trial & 21 & $\begin{array}{c}2 \mathrm{mg} / \mathrm{kg} / \text { day of aprinocarsen was administered for } \\
21 \text { days per month }\end{array}$ & $\begin{array}{l}1.2 \text { months } \\
\text { (median) }\end{array}$ & 3.4 months \\
\hline
\end{tabular}

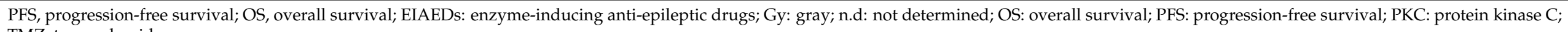

TMZ: temozolomide. 
Undoubtedly, the most relevant clinical trials implicating PKC in GBM so far have analyzed the effects of enzastaurine. This small molecule is an inhibitor of PKC $\beta$ that has been used for the treatment of a variety of tumors and, similarly to tamoxifen, is a lipid soluble compound that can cross the BBB. Enzastaurin was originally developed as an anti-angiogenic agent based on the role of PKC $\beta$ in angiogenesis [125,172-174]. However, its specificity is not very high for PKC $\beta$ since, at higher concentrations, the drug can inhibit other PKC isoforms including PKC $\alpha[172,173]$. Despite this, enzastaurin has shown a longer half-life than TMZ (12-40 h vs. $1.8 \mathrm{~h}$ ) and remarkable radiographic response rates in recurrent high-grade gliomas [168,169]. Although a phase III clinical trial failed to demonstrate such efficacy after comparing the monotherapies of enzastaurin and lomustine in recurrent GBM, the PFS was 1.5 months and OS was 6.6 months [126]. Therefore, these trials did not improve the effectiveness of current treatments, even in combination with lomustine, a nitrosourea that interacts with DNA, commonly used as a chemoterapeutic agent $[126,166,167]$. Other strategies have been explored-such as a combination with bevacizumab — with no further improvement [170]. Therefore, clinical trials using the PKC inhibitor enzastaurin have not succeeded at limiting GBM progression and invasion, either alone, or in combination with TMZ or other compounds. In addition to tamoxifen and enzastaurin, a trial to test the PKC $\alpha$ inhibitor aprinocarsen has been carried out without success [171].

As stated above, the tumor microenvironment and intra-tumor heterogeneity should be considered as responsible for the lack of improvement found in phase III trials with enzastaurin. Alteration of PKC expression and activity among the different cell types within the tumor needs also to be considered. Alternatively, enzastaurin itself might modify PKC expression or alter the signaling cascades that interact with PKC activity, creating resistance. Thus, identification of signaling cascades associated with PKC and compounds that target these molecules might help in the design of additional therapies that overcome intra-tumor heterogeneity and TME induced evolution.

\section{A Connection between GBM Tumorigenesis, EGFR Signaling and PKC Isozymes}

RTKs have long been targeted in the treatment of GBM [175]. As explained above, PKCs are intimately related with the EGFR signaling pathway which is responsible for the proliferation and survival of GBM. This receptor is an RTK that belongs to the ErbB family of receptors (EGFR, Her2, ErbB3 and ErbB4) [176]. EGFR can be activated by numerous ligands such as EGF, TGF $\alpha$, heparin-binding EGF-like growth factor (HB-EGF), amphiregulin and epiregulin. Stimulation of the EGFR dependent signaling pathways, PI3K-AKT and mTOR, MAPK-Erk, or JAK/STAT, transduces signals into the nucleus, leading to gene expression changes that are responsible for tumor proliferation, genetic immortality, invasion, angiogenesis, and the avoidance of immune surveillance [177]. ErbB3 and ErbB4 bind neuregulins are activating signaling pathways with antiproliferative and differentiating effects. One of the most common mutations in GBM is the appearance of EGFRvIII via deletion of exons 2 to 7 , that leads to a constitutively active EGFR that is not regulated by endocytosis [178].

Another molecule of interest in GBM treatment is PI3K. Due to the effect of PTEN loss in GBM growth, survival and migration, PI3K inhibitors have been used in clinical trials but have yielded little success $[179,180]$. The failure of these inhibitors may be related to their specificity to inhibit only one of the two PI3K isoforms (p110a or p110b).

It is now known that specific PKC isozymes participate in the release of specific ErbB ligands: phosphorylation of the membrane-bound pro-ligands facilitates their ectodomain shedding in a reaction catalyzed by ADAM17. Thus, classical PKC isozymes promote the release of EGFR and Her2 ligands, whereas novel PKC isozymes promote the release of ErbB4 ligands neuregulins $[116,117,181]$. Therefore, PKCs not only regulate intracellular signaling cascades initiated by the EGFR receptor, but as a main function, they also regulate the initiation of these signaling pathways. Taking these facts into consideration, it seems reasonable to hypothesize that regulating the activity of specific PKC isozymes (i.e., ac- 
tivating the novel PKC isozymes and inhibiting the classical variants) may result in an interesting strategy to halt GBM growth and survival, migration and invasion.

\section{Future Perspectives}

PKC enzymes have been reported to play a complex role in GBM development and prognosis. As shown in this review, the different isozymes participate in growth, survival, and invasiveness of GBM. Additionally, they are involved in initiating EGFR ligand release, which is one of the main signaling pathway leading to GBM proliferation, migration and invasiveness (see Figure 4). Thus, inhibiting classical PKC isozymes may result in a reduction in GBM proliferation and tumor progression because of the inhibition of the EGFR pathway. Although preclinical studies indicate that the specific activation of PKC enzymes may result in adequate cancer treatments, the use of the PKC $\beta$ inhibitor enzastaurin in clinical trials did not show a better efficacy than current GBM treatment drugs. Except for the recent study by Cullen et al. [111], in which a library of putative PKC activating compounds were tested for the treatment of melanoma, most of the classical PKC activators used so far in cancer studies promote the sustained irreversible enzyme activation and degradation and lack specificity for individual isozymes such as PMA. It has recently been proposed that, in order to target PKC for cancer treatment, therapies should better focus on the induction or re-establishment of specific PKC activities rather than on the inhibition of these enzymes.

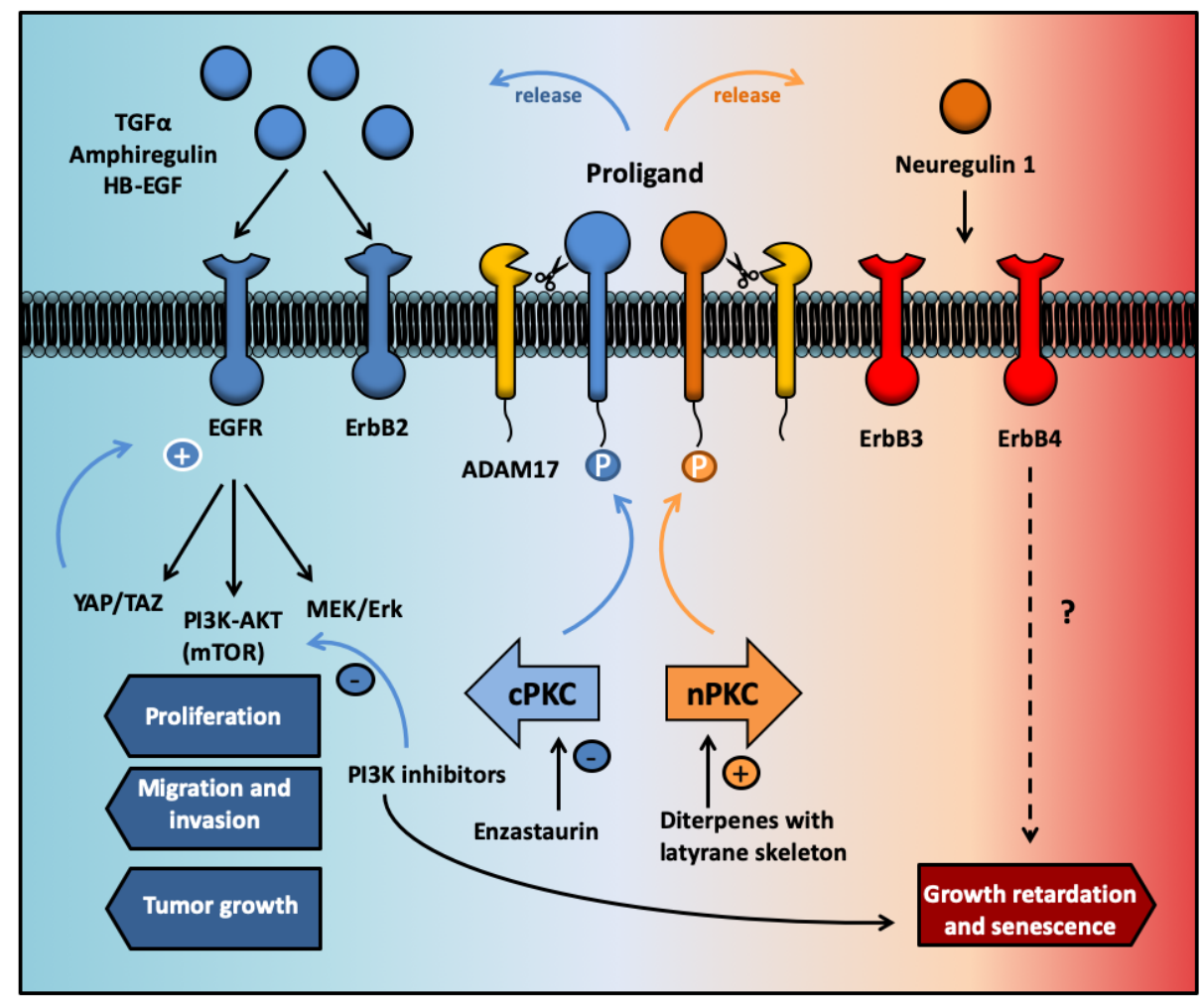

Figure 4. The selective activation of different PKC isozymes may lead to the release of different growth factors, which will differentially activate ErbB receptors with different cells functions. Activation of epidermal growth factor receptor (EGFR) by ligands released in an ADAM17-mediated manner stimulate intracellular pathways leading to cell proliferation, cell cycle entrance and GBM growth. The use of enzastaurin inhibits these pathways. In addition to this drug, activation of novel PKC isozymes may facilitate the ADAM17-mediated release of neuregulins, stimulating differentiation and inhibiting proliferation survival and growth.

For this purpose, we require drug screenings to reveal novel molecules that specifically activate each isozyme in a reversible manner, without causing the down-regulation or 
degradation of their ligand. We propose in Figure 4 that the selective activation of different PKC isozymes may lead to the release of different growth factors, which will differentially activate ErbB receptors to modulate different cell functions. Thus, the activation of classical PKC may lead to EGFR ligand release and-as a consequence- to the activation of EGFRdependent proliferation and the survival of GBM. Conversely, the activation of novel PKC may lead to the release of ADAM17-dependent neuregulins, impairing EGFR ligand release and slowing down GBM proliferation and growth. We hypothesize that the combination of these PKC targeting drugs with current treatments may enhance prognosis and survival time. Diterpenes with the capacity to individually regulate classical and novel PKC have recently been described for use in neuronal regeneration [113,114] and as putative treatments for other cancer types [111]. Thus, these agents could prove useful in the development of drugs either in standalone or in combined strategies with other compounds (e.g., PI3K inhibitors).

Author Contributions: Conceptualization, C.C., L.M.V., P.N.-A., J.L.G.-S. writing-original draft preparation, N.G.-D., I.H.-C.; writing-review and editing, N.G.-D., I.H.-C., R.G.-O., S.D.-G., F.A.R., C.C., P.N.-A., I.I.-L., L.C., R.P.-D. and L.C.; supervision, C.C., L.M.V., P.N.-A.; funding acquisition, C.C. and L.M.V. All authors have read and agreed to the published version of the manuscript.

Funding: This research was co-financed by the Integrated Territorial Investment Operational Programme of the European Commission and by the Department of Department of Health and Families (Consejería de Salud y Familias) of the Regional Government of Andalusia. Project reference: ITI0042-2019: ITI Cadiz 2019. L.M.V. is the recipient of a Miguel Servet II contract (CPII20/00025) financed by the Instituto de Salud Carlos III and Fondo Social Europeo 2014-2020, Programa Estatal de Promoción del Talento y su empleabilidad en I + D + i.

Conflicts of Interest: The authors declare no conflict of interest.

\section{Abbreviations}

$\begin{array}{ll}\text { ACNU } & \text { Nimustine } \\ \text { ASCL1 } & \text { Achaete-scute complex homolog-1 } \\ \text { ATRX } & \text { Alpha thalassemia/mental retardation syndrome X-linked } \\ \text { BBB } & \text { Blood-brain barrier } \\ \text { BCNU } & \text { Carmustine } \\ \text { bFGF } & \text { Basic fibroblast growth factor } \\ \text { CCNU } & \text { Lomustine } \\ \text { CD133 } & \text { Prominin1 } \\ \text { CNS WHO } & \text { World Health Organization Classification of Tumors of the Central Nervous System } \\ \text { CNS } & \text { Central nervous system } \\ \text { DAG } & \text { Diacylglycerol } \\ \text { DCX } & \text { Doublecortin } \\ \text { DG } & \text { Dentate gyrus } \\ \text { DLX2 } & \text { Distal-less homeobox2 } \\ \text { EC } & \text { Endothelial cells } \\ \text { EGFR } & \text { Epidermal growth factor receptor } \\ \text { FGFR } & \text { Fibroblast growth factor receptor } \\ \text { GBM } & \text { Glioblastomas } \\ \text { GD3 } & \text { GD3 ganglioside } \\ \text { GFAP } & \text { Glial fibrillary acidic protein } \\ \text { GLAST } & \text { Astrocytic glutamate transporter } \\ \text { GPDH } & \text { Glycerol-3-phosphate dehydrogenase } \\ \text { GSC } & \text { Glioma stem cells } \\ \text { HB-EGF } & \text { EGF-like growth factor } \\ \text { HGFR/c-MET } & \text { Hepatocyte growth factor receptor/mesenchymal-epithelial transition factor } \\ \text { IDH 1, IDH2 } & \text { Isocitrate dehydrogenase 1 and 2 } \\ \text { JAK2 } & \text { Janus kinase 2 } \\ \text { LIMK } & \text { MEC-3 protein domain kinase } \\ & \end{array}$




$\begin{array}{ll}\text { MAG } & \text { Myelin associated glycoprotein } \\ \text { MAP2 } & \text { Microtubule associated protein 2 } \\ \text { MBP } & \text { Myelin basic protein } \\ \text { MGMT } & \text { O6-methylguanine-DNA methyltransferase } \\ \text { NeuN } & \text { Hexaribonucleotide Binding Protein-3 } \\ \text { NG2 } & \text { Neuron-glial antigen 2 } \\ \text { NOS } & \text { Not Otherwise Specified } \\ \text { NPCs } & \text { Neural progenitor cells } \\ \text { NSCs } & \text { Neural stem cells } \\ \text { O4 } & \text { Surface antigen O4 } \\ \text { OB } & \text { Olfactory bulb } \\ \text { OS } & \text { Overall survival } \\ \text { PDGFR } & \text { Platelet-derived growth factor receptor } \\ \text { PDGFRa } & \text { Platelet derived growth factor receptor alpha } \\ \text { PFS } & \text { Progression-free survival } \\ \text { PKC } & \text { Protein kinase C } \\ \text { PMA } & \text { Phorbol myristate acetate } \\ \text { PS } & \text { Phosphatidyl serine } \\ \text { PSA-NCAM } & \text { Polysyalated-neural cell adhesion molecule } \\ \text { PTEN } & \text { Phosphatase and tensin homolog } \\ \text { RTKs } & \text { Tyrosin kinase receptors } \\ \text { SOX2 } & \text { Sex determining region Y-box 2 } \\ \text { SVZ } & \text { Subventricular zone } \\ \text { TERT } & \text { Telomerase reverse transcriptase } \\ \text { TME } & \text { Tumor microenvironment } \\ \text { TMZ } & \text { Temozolomide } \\ \text { TRAIL } & \text { TNF-related apoptosis-inducing ligand } \\ \text { Tuj1 } & \text { Neuron-specific class III beta-tubulin } \\ \text { VEGFR } & \text { Vascular endothelial growth factor receptor } \\ & \end{array}$

\section{References}

1. Goodenberger, M.L.; Jenkins, R.B. Genetics of adult glioma. Cancer Genet. 2012, 205, 613-621. [CrossRef] [PubMed]

2. Bray, F.; Ferlay, J.; Soerjomataram, I.; Siegel, R.L.; Torre, L.A.; Jemal, A. Global cancer statistics 2018: GLOBOCAN estimates of incidence and mortality worldwide for 36 cancers in 185 countries. Ca Cancer J. Clin. 2018, 68, 394-424. [CrossRef] [PubMed]

3. Molinaro, A.M.; Taylor, J.W.; Wiencke, J.K.; Wrensch, M.R. Genetic and molecular epidemiology of adult diffuse glioma. Nat. Rev. Neurol. 2019, 15, 405-417. [CrossRef]

4. Suresh, S.G.; Srinivasan, A.; Scott, J.X.; Rao, S.M.; Chidambaram, B.; Chandrasekar, S. Profile and Outcome of Pediatric Brain Tumors-Experience from a Tertiary Care Pediatric Oncology Unit in South India. J. Pediatr. Neurosci. 2017, 12, 237-244. [CrossRef] [PubMed]

5. Miranda-Filho, A.; Pineros, M.; Soerjomataram, I.; Deltour, I.; Bray, F. Cancers of the brain and CNS: Global patterns and trends in incidence. Neuro. Oncol. 2017, 19, 270-280. [CrossRef] [PubMed]

6. Ohgaki, H.; Kleihues, P. The definition of primary and secondary glioblastoma. Clin. Cancer Res. 2013, 19, 764-772. [CrossRef] [PubMed]

7. Tamimi, A.F.; Juweid, M. Epidemiology and Outcome of Glioblastoma. In Glioblastoma; De Vleeschouwer, S., Ed.; Exon Publications: Brisbane, Australia, 2017. [CrossRef]

8. Ostrom, Q.T.; Kinnersley, B.; Wrensch, M.R.; Eckel-Passow, J.E.; Armstrong, G.; Rice, T.; Chen, Y.; Wiencke, J.K.; McCoy, L.S.; Hansen, H.M.; et al. Sex-specific glioma genome-wide association study identifies new risk locus at $3 \mathrm{p} 21.31$ in females, and finds sex-differences in risk at 8q24.21. Sci. Rep. 2018, 8, 7352. [CrossRef] [PubMed]

9. Hanif, F.; Muzaffar, K.; Perveen, K.; Malhi, S.M.; Simjee Sh, U. Glioblastoma Multiforme: A Review of its Epidemiology and Pathogenesis through Clinical Presentation and Treatment. Asian Pac. J. Cancer Prev. 2017, 18, 3-9. [CrossRef]

10. Iacob, G.; Dinca, E.B. Current data and strategy in glioblastoma multiforme. J. Med. Life 2009, 2, 386-393.

11. Chakrabarti, I.; Cockburn, M.; Cozen, W.; Wang, Y.P.; Preston-Martin, S. A population-based description of glioblastoma multiforme in Los Angeles County, 1974-1999. Cancer 2005, 104, 2798-2806. [CrossRef]

12. Adams, H.; Chaichana, K.L.; Avendano, J.; Liu, B.; Raza, S.M.; Quinones-Hinojosa, A. Adult cerebellar glioblastoma: Understanding survival and prognostic factors using a population-based database from 1973 to 2009. World Neurosurg. 2013, 80, e237-e243. [CrossRef] [PubMed]

13. Hamilton, S.R.; Liu, B.; Parsons, R.E.; Papadopoulos, N.; Jen, J.; Powell, S.M.; Krush, A.J.; Berk, T.; Cohen, Z.; Tetu, B.; et al. The molecular basis of Turcot's syndrome. N. Engl. J. Med. 1995, 332, 839-847. [CrossRef] [PubMed] 
14. Kleihues, P.; Ohgaki, H. Primary and secondary glioblastomas: From concept to clinical diagnosis. Neuro Oncol. 1999, 1, 44-51. [CrossRef] [PubMed]

15. Louis, D.N.; Perry, A.; Reifenberger, G.; von Deimling, A.; Figarella-Branger, D.; Cavenee, W.K.; Ohgaki, H.; Wiestler, O.D.; Kleihues, P.; Ellison, D.W. The 2016 World Health Organization Classification of Tumors of the Central Nervous System: A summary. Acta Neuropathol. 2016, 131, 803-820. [CrossRef]

16. Cancer Genome Atlas Research Network; Brat, D.J.; Verhaak, R.G.; Aldape, K.D.; Yung, W.K.; Salama, S.R.; Cooper, L.A.; Rheinbay, E.; Miller, C.R.; Vitucci, M.; et al. Comprehensive, Integrative Genomic Analysis of Diffuse Lower-Grade Gliomas. N. Engl. J. Med. 2015, 372, 2481-2498. [CrossRef] [PubMed]

17. Sahm, F.; Reuss, D.; Koelsche, C.; Capper, D.; Schittenhelm, J.; Heim, S.; Jones, D.T.; Pfister, S.M.; Herold-Mende, C.; Wick, W.; et al. Farewell to oligoastrocytoma: In situ molecular genetics favor classification as either oligodendroglioma or astrocytoma. Acta Neuropathol. 2014, 128, 551-559. [CrossRef]

18. Wiestler, B.; Capper, D.; Sill, M.; Jones, D.T.; Hovestadt, V.; Sturm, D.; Koelsche, C.; Bertoni, A.; Schweizer, L.; Korshunov, A.; et al. Integrated DNA methylation and copy-number profiling identify three clinically and biologically relevant groups of anaplastic glioma. Acta Neuropathol. 2014, 128, 561-571. [CrossRef] [PubMed]

19. Ostrom, Q.T.; Gittleman, H.; Truitt, G.; Boscia, A.; Kruchko, C.; Barnholtz-Sloan, J.S. CBTRUS Statistical Report: Primary Brain and Other Central Nervous System Tumors Diagnosed in the United States in 2011-2015. Neuro Oncol. 2018, 20, iv1-iv86. [CrossRef] [PubMed]

20. Yip, S.; Butterfield, Y.S.; Morozova, O.; Chittaranjan, S.; Blough, M.D.; An, J.; Birol, I.; Chesnelong, C.; Chiu, R.; Chuah, E.; et al. Concurrent CIC mutations, IDH mutations, and 1p/19q loss distinguish oligodendrogliomas from other cancers. J. Pathol. 2012, 226, 7-16. [CrossRef] [PubMed]

21. Buckner, J.; Giannini, C.; Eckel-Passow, J.; Lachance, D.; Parney, I.; Laack, N.; Jenkins, R. Management of diffuse low-grade gliomas in adults-Use of molecular diagnostics. Nat. Rev. Neurol. 2017, 13, 340-351. [CrossRef]

22. Wiestler, B.; Capper, D.; Holland-Letz, T.; Korshunov, A.; von Deimling, A.; Pfister, S.M.; Platten, M.; Weller, M.; Wick, W. ATRX loss refines the classification of anaplastic gliomas and identifies a subgroup of IDH mutant astrocytic tumors with better prognosis. Acta Neuropathol. 2013, 126, 443-451. [CrossRef] [PubMed]

23. Dahlrot, R.H.; Dowsett, J.; Fosmark, S.; Malmstrom, A.; Henriksson, R.; Boldt, H.; de Stricker, K.; Sorensen, M.D.; Poulsen, H.S.; Lysiak, M.; et al. Prognostic value of O-6-methylguanine-DNA methyltransferase (MGMT) protein expression in glioblastoma excluding nontumour cells from the analysis. Neuropathol. Appl. Neurobiol. 2018, 44, 172-184. [CrossRef] [PubMed]

24. Brennan, C.W.; Verhaak, R.G.; McKenna, A.; Campos, B.; Noushmehr, H.; Salama, S.R.; Zheng, S.; Chakravarty, D.; Sanborn, J.Z.; Berman, S.H.; et al. The somatic genomic landscape of glioblastoma. Cell 2013, 155, 462-477. [CrossRef] [PubMed]

25. Vinagre, J.; Almeida, A.; Populo, H.; Batista, R.; Lyra, J.; Pinto, V.; Coelho, R.; Celestino, R.; Prazeres, H.; Lima, L.; et al. Frequency of TERT promoter mutations in human cancers. Nat. Commun. 2013, 4, 2185. [CrossRef] [PubMed]

26. Killela, P.J.; Reitman, Z.J.; Jiao, Y.; Bettegowda, C.; Agrawal, N.; Diaz, L.A.; Friedman, A.H.; Friedman, H.; Gallia, G.L.; Giovanella, B.C.; et al. TERT promoter mutations occur frequently in gliomas and a subset of tumors derived from cells with low rates of self-renewal. Proc. Natl. Acad. Sci. USA 2013, 110, 6021-6026. [CrossRef] [PubMed]

27. Lee, Y.; Koh, J.; Kim, S.I.; Won, J.K.; Park, C.K.; Choi, S.H.; Park, S.H. The frequency and prognostic effect of TERT promoter mutation in diffuse gliomas. Acta Neuropathol. Commun. 2017, 5, 62. [CrossRef]

28. Mellinghoff, I.K.; Wang, M.Y.; Vivanco, I.; Haas-Kogan, D.A.; Zhu, S.; Dia, E.Q.; Lu, K.V.; Yoshimoto, K.; Huang, J.H.; Chute, D.J.; et al. Molecular determinants of the response of glioblastomas to EGFR kinase inhibitors. N. Engl. J. Med. 2005, 353, 2012-2024. [CrossRef]

29. Gómez-Oliva, R.; Domínguez-García, S.; Carrascal, L.; Abalos-Martínez, J.; Pardillo-Díaz, R.; Verástegui, C.; Castro, C.; NunezAbades, P.; Geribaldi-Doldán, N. Evolution of Experimental Models in the Study of Glioblastoma: Toward Finding Efficient Treatments. Front. Oncol. 2021, 10, 3245. [CrossRef]

30. Altman, J. Are new neurons formed in the brains of adult mammals? Science 1962, 135, 1127-1128. [CrossRef]

31. Reynolds, B.A.; Weiss, S. Generation of neurons and astrocytes from isolated cells of the adult mammalian central nervous system. Science 1992, 255, 1707-1710. [CrossRef] [PubMed]

32. Alvarez-Buylla, A.; Garcia-Verdugo, J.M. Neurogenesis in adult subventricular zone. J. Neurosci. Off. J. Soc. Neurosci. 2002, 22, 629-634. [CrossRef]

33. Goldman, S. Glia as neural progenitor cells. Trends Neurosci. 2003, 26, 590-596. [CrossRef] [PubMed]

34. Silva-Vargas, V.; Delgado, A.C.; Doetsch, F. Symmetric Stem Cell Division at the Heart of Adult Neurogenesis. Neuron 2018, 98, 246-248. [CrossRef] [PubMed]

35. Kuhn, H.G.; Dickinson-Anson, H.; Gage, F.H. Neurogenesis in the dentate gyrus of the adult rat: Age-related decrease of neuronal progenitor proliferation. J. Neurosci. Off. J. Soc. Neurosci. 1996, 16, 2027-2033. [CrossRef]

36. Doetsch, F.; Garcia-Verdugo, J.M.; Alvarez-Buylla, A. Cellular composition and three-dimensional organization of the subventricular germinal zone in the adult mammalian brain. J. Neurosci. Off. J. Soc. Neurosci. 1997, 17, 5046-5061. [CrossRef]

37. Spalding, K.L.; Bergmann, O.; Alkass, K.; Bernard, S.; Salehpour, M.; Huttner, H.B.; Bostrom, E.; Westerlund, I.; Vial, C.; Buchholz, B.A.; et al. Dynamics of hippocampal neurogenesis in adult humans. Cell 2013, 153, 1219-1227. [CrossRef]

38. Dennis, C.V.; Suh, L.S.; Rodriguez, M.L.; Kril, J.J.; Sutherland, G.T. Human adult neurogenesis across the ages: An immunohistochemical study. Neuropathol. Appl. Neurobiol. 2016, 42, 621-638. [CrossRef] [PubMed] 
39. Eriksson, P.S.; Perfilieva, E.; Bjork-Eriksson, T.; Alborn, A.M.; Nordborg, C.; Peterson, D.A.; Gage, F.H. Neurogenesis in the adult human hippocampus. Nat. Med. 1998, 4, 1313-1317. [CrossRef] [PubMed]

40. Sorrells, S.F.; Paredes, M.F.; Cebrian-Silla, A.; Sandoval, K.; Qi, D.; Kelley, K.W.; James, D.; Mayer, S.; Chang, J.; Auguste, K.I.; et al. Human hippocampal neurogenesis drops sharply in children to undetectable levels in adults. Nature 2018, 555, 377-381. [CrossRef]

41. Lim, D.A.; Alvarez-Buylla, A. The Adult Ventricular-Subventricular Zone (V-SVZ) and Olfactory Bulb (OB) Neurogenesis. Cold Spring Harb. Perspect. Biol. 2016, 8, a018820. [CrossRef]

42. Mirzadeh, Z.; Merkle, F.T.; Soriano-Navarro, M.; Garcia-Verdugo, J.M.; Alvarez-Buylla, A. Neural stem cells confer unique pinwheel architecture to the ventricular surface in neurogenic regions of the adult brain. Cell Stem Cell 2008, 3, 265-278. [CrossRef]

43. Ponti, G.; Obernier, K.; Alvarez-Buylla, A. Lineage progression from stem cells to new neurons in the adult brain ventricularsubventricular zone. Cell Cycle 2013, 12, 1649-1650. [CrossRef] [PubMed]

44. Garcia-Verdugo, J.M.; Doetsch, F.; Wichterle, H.; Lim, D.A.; Alvarez-Buylla, A. Architecture and cell types of the adult subventricular zone: In search of the stem cells. J. Neurobiol. 1998, 36, 234-248. [CrossRef]

45. Ortega, F.; Berninger, B.; Costa, M.R. Primary culture and live imaging of adult neural stem cells and their progeny. Methods Mol. Biol. 2013, 1052, 1-11. [CrossRef] [PubMed]

46. Alvarez-Buylla, A.; Seri, B.; Doetsch, F. Identification of neural stem cells in the adult vertebrate brain. Brain Res. Bull. 2002, 57, 751-758. [CrossRef]

47. Urban, N.; Guillemot, F. Neurogenesis in the embryonic and adult brain: Same regulators, different roles. Front. Cell. Neurosci. 2014, 8, 396. [CrossRef]

48. Giachino, C.; Taylor, V. Lineage analysis of quiescent regenerative stem cells in the adult brain by genetic labelling reveals spatially restricted neurogenic niches in the olfactory bulb. Eur. J. Neurosci. 2009, 30, 9-24. [CrossRef]

49. Gengatharan, A.; Bammann, R.R.; Saghatelyan, A. The Role of Astrocytes in the Generation, Migration, and Integration of New Neurons in the Adult Olfactory Bulb. Front. Neurosci. 2016, 10, 149. [CrossRef]

50. De Almeida Sassi, F.; Lunardi Brunetto, A.; Schwartsmann, G.; Roesler, R.; Abujamra, A.L. Glioma revisited: From neurogenesis and cancer stem cells to the epigenetic regulation of the niche. J. Oncol. 2012, 2012, 537861. [CrossRef] [PubMed]

51. Jafri, N.F.; Clarke, J.L.; Weinberg, V.; Barani, I.J.; Cha, S. Relationship of glioblastoma multiforme to the subventricular zone is associated with survival. Neuro Oncol. 2013, 15, 91-96. [CrossRef]

52. Adeberg, S.; Bostel, T.; Konig, L.; Welzel, T.; Debus, J.; Combs, S.E. A comparison of long-term survivors and short-term survivors with glioblastoma, subventricular zone involvement: A predictive factor for survival? Radiat. Oncol. 2014, 9, 95. [CrossRef]

53. Sonoda, Y.; Saito, R.; Kanamori, M.; Kumabe, T.; Uenohara, H.; Tominaga, T. The association of subventricular zone involvement at recurrence with survival after repeat surgery in patients with recurrent glioblastoma. Neurol. Med. Chir. 2014, 54, 302-309. [CrossRef] [PubMed]

54. Shen, Q.; Wang, Y.; Kokovay, E.; Lin, G.; Chuang, S.M.; Goderie, S.K.; Roysam, B.; Temple, S. Adult SVZ stem cells lie in a vascular niche: A quantitative analysis of niche cell-cell interactions. Cell Stem Cell 2008, 3, 289-300. [CrossRef]

55. Tavazoie, M.; Van der Veken, L.; Silva-Vargas, V.; Louissaint, M.; Colonna, L.; Zaidi, B.; Garcia-Verdugo, J.M.; Doetsch, F. A specialized vascular niche for adult neural stem cells. Cell Stem Cell 2008, 3, 279-288. [CrossRef] [PubMed]

56. Karow, M.; Sanchez, R.; Schichor, C.; Masserdotti, G.; Ortega, F.; Heinrich, C.; Gascon, S.; Khan, M.A.; Lie, D.C.; Dellavalle, A.; et al. Reprogramming of pericyte-derived cells of the adult human brain into induced neuronal cells. Cell Stem Cell 2012, 11, 471-476. [CrossRef] [PubMed]

57. Brem, S.; Cotran, R.; Folkman, J. Tumor angiogenesis: A quantitative method for histologic grading. J. Natl. Cancer Inst. 1972, 48, 347-356. [PubMed]

58. Calabrese, C.; Poppleton, H.; Kocak, M.; Hogg, T.L.; Fuller, C.; Hamner, B.; Oh, E.Y.; Gaber, M.W.; Finklestein, D.; Allen, M.; et al. A perivascular niche for brain tumor stem cells. Cancer Cell 2007, 11, 69-82. [CrossRef]

59. Guelfi, S.; Duffau, H.; Bauchet, L.; Rothhut, B.; Hugnot, J.P. Vascular Transdifferentiation in the CNS: A Focus on Neural and Glioblastoma Stem-Like Cells. Stem Cells Int. 2016, 2016, 2759403. [CrossRef]

60. Hardee, M.E.; Zagzag, D. Mechanisms of glioma-associated neovascularization. Am. J. Pathol. 2012, 181, 1126-1141. [CrossRef] [PubMed]

61. Ricci-Vitiani, L.; Pallini, R.; Biffoni, M.; Todaro, M.; Invernici, G.; Cenci, T.; Maira, G.; Parati, E.A.; Stassi, G.; Larocca, L.M.; et al. Tumour vascularization via endothelial differentiation of glioblastoma stem-like cells. Nature 2010, 468, 824-828. [CrossRef] [PubMed]

62. Shen, Q.; Goderie, S.K.; Jin, L.; Karanth, N.; Sun, Y.; Abramova, N.; Vincent, P.; Pumiglia, K.; Temple, S. Endothelial cells stimulate self-renewal and expand neurogenesis of neural stem cells. Science 2004, 304, 1338-1340. [CrossRef] [PubMed]

63. Sanai, N.; Tramontin, A.D.; Quinones-Hinojosa, A.; Barbaro, N.M.; Gupta, N.; Kunwar, S.; Lawton, M.T.; McDermott, M.W.; Parsa, A.T.; Manuel-Garcia Verdugo, J.; et al. Unique astrocyte ribbon in adult human brain contains neural stem cells but lacks chain migration. Nature 2004, 427, 740-744. [CrossRef] [PubMed]

64. Sawamoto, K.; Hirota, Y.; Alfaro-Cervello, C.; Soriano-Navarro, M.; He, X.; Hayakawa-Yano, Y.; Yamada, M.; Hikishima, K.; Tabata, H.; Iwanami, A.; et al. Cellular composition and organization of the subventricular zone and rostral migratory stream in the adult and neonatal common marmoset brain. J. Comp. Neurol. 2011, 519, 690-713. [CrossRef] [PubMed] 
65. Quinones-Hinojosa, A.; Sanai, N.; Soriano-Navarro, M.; Gonzalez-Perez, O.; Mirzadeh, Z.; Gil-Perotin, S.; Romero-Rodriguez, R.; Berger, M.S.; Garcia-Verdugo, J.M.; Alvarez-Buylla, A. Cellular composition and cytoarchitecture of the adult human subventricular zone: A niche of neural stem cells. J. Comp. Neurol. 2006, 494, 415-434. [CrossRef] [PubMed]

66. Charles, N.; Holland, E.C. The perivascular niche microenvironment in brain tumor progression. Cell Cycle 2010, 9, 3012-3021. [CrossRef]

67. Mohyeldin, A.; Garzon-Muvdi, T.; Quinones-Hinojosa, A. Oxygen in stem cell biology: A critical component of the stem cell niche. Cell Stem Cell 2010, 7, 150-161. [CrossRef]

68. Folkins, C.; Shaked, Y.; Man, S.; Tang, T.; Lee, C.R.; Zhu, Z.; Hoffman, R.M.; Kerbel, R.S. Glioma tumor stem-like cells promote tumor angiogenesis and vasculogenesis via vascular endothelial growth factor and stromal-derived factor 1. Cancer Res. 2009, 69, 7243-7251. [CrossRef]

69. Bar, E.E.; Lin, A.; Mahairaki, V.; Matsui, W.; Eberhart, C.G. Hypoxia increases the expression of stem-cell markers and promotes clonogenicity in glioblastoma neurospheres. Am. J. Pathol. 2010, 177, 1491-1502. [CrossRef] [PubMed]

70. Sanai, N.; Alvarez-Buylla, A.; Berger, M.S. Neural stem cells and the origin of gliomas. N. Engl. J. Med. 2005, 353, 811-822. [CrossRef]

71. Tohyama, T.; Lee, V.M.; Rorke, L.B.; Marvin, M.; McKay, R.D.; Trojanowski, J.Q. Nestin expression in embryonic human neuroepithelium and in human neuroepithelial tumor cells. Lab. Investig. J. Tech. Methods Pathol. 1992, 66, 303-313.

72. Xie, Z. Brain tumor stem cells. Neurochem. Res. 2009, 34, 2055-2066. [CrossRef]

73. Galli, R.; Binda, E.; Orfanelli, U.; Cipelletti, B.; Gritti, A.; De Vitis, S.; Fiocco, R.; Foroni, C.; Dimeco, F.; Vescovi, A. Isolation and characterization of tumorigenic, stem-like neural precursors from human glioblastoma. Cancer Res. 2004, 64, 7011-7021. [CrossRef]

74. Yuan, X.; Curtin, J.; Xiong, Y.; Liu, G.; Waschsmann-Hogiu, S.; Farkas, D.L.; Black, K.L.; Yu, J.S. Isolation of cancer stem cells from adult glioblastoma multiforme. Oncogene 2004, 23, 9392-9400. [CrossRef] [PubMed]

75. Ignatova, T.N.; Kukekov, V.G.; Laywell, E.D.; Suslov, O.N.; Vrionis, F.D.; Steindler, D.A. Human cortical glial tumors contain neural stem-like cells expressing astroglial and neuronal markers in vitro. Glia 2002, 39, 193-206. [CrossRef] [PubMed]

76. Ludwig, K.; Kornblum, H.I. Molecular markers in glioma. J. Neuro Oncol. 2017, 134, 505-512. [CrossRef]

77. Beier, D.; Hau, P.; Proescholdt, M.; Lohmeier, A.; Wischhusen, J.; Oefner, P.J.; Aigner, L.; Brawanski, A.; Bogdahn, U.; Beier, C.P. CD133(+) and CD133(-) glioblastoma-derived cancer stem cells show differential growth characteristics and molecular profiles. Cancer Res. 2007, 67, 4010-4015. [CrossRef] [PubMed]

78. Shmelkov, S.V.; St Clair, R.; Lyden, D.; Rafii, S. AC133/CD133/Prominin-1. Int. J. Biochem. Cell Biol. 2005, 37, 715-719. [CrossRef]

79. Schmohl, J.U.; Vallera, D.A. CD133, Selectively Targeting the Root of Cancer. Toxins 2016, 8, 165. [CrossRef]

80. Irollo, E.; Pirozzi, G. CD133: To be or not to be, is this the real question? Am. J. Transl. Res. 2013, 5, 563-581.

81. Yip, S.; Iafrate, A.J.; Louis, D.N. Molecular diagnostic testing in malignant gliomas: A practical update on predictive markers. J. Neuropathol. Exp. Neurol. 2008, 67, 1-15. [CrossRef]

82. Capela, A.; Temple, S. LeX is expressed by principle progenitor cells in the embryonic nervous system, is secreted into their environment and binds Wnt-1. Dev. Biol. 2006, 291, 300-313. [CrossRef] [PubMed]

83. Liu, X.Y.; Gerges, N.; Korshunov, A.; Sabha, N.; Khuong-Quang, D.A.; Fontebasso, A.M.; Fleming, A.; Hadjadj, D.; Schwartzentruber, J.; Majewski, J.; et al. Frequent ATRX mutations and loss of expression in adult diffuse astrocytic tumors carrying IDH1/IDH2 and TP53 mutations. Acta Neuropathol. 2012, 124, 615-625. [CrossRef]

84. Brescia, P.; Richichi, C.; Pelicci, G. Current strategies for identification of glioma stem cells: Adequate or unsatisfactory? J. Oncol. 2012, 2012, 376894. [CrossRef]

85. Heddleston, J.M.; Li, Z.; McLendon, R.E.; Hjelmeland, A.B.; Rich, J.N. The hypoxic microenvironment maintains glioblastoma stem cells and promotes reprogramming towards a cancer stem cell phenotype. Cell Cycle 2009, 8, 3274-3284. [CrossRef] [PubMed]

86. Schiffer, D.; Mellai, M.; Annovazzi, L.; Caldera, V.; Piazzi, A.; Denysenko, T.; Melcarne, A. Stem cell niches in glioblastoma: A neuropathological view. Biomed. Res. Int. 2014, 2014, 725921. [CrossRef]

87. Regad, T. Targeting RTK Signaling Pathways in Cancer. Cancers 2015, 7, 1758-1784. [CrossRef]

88. Cancer Genome Atlas Research Network. Comprehensive genomic characterization defines human glioblastoma genes and core pathways. Nature 2008, 455, 1061-1068. [CrossRef] [PubMed]

89. Huang, P.H.; Xu, A.M.; White, F.M. Oncogenic EGFR signaling networks in glioma. Sci. Signal. 2009, 2, re6. [CrossRef]

90. Shibuya, M. Structure and function of VEGF/VEGF-receptor system involved in angiogenesis. Cell Struct. Funct. 2001, 26, 25-35. [CrossRef] [PubMed]

91. Morrison, R.S.; Yamaguchi, F.; Bruner, J.M.; Tang, M.; McKeehan, W.; Berger, M.S. Fibroblast growth factor receptor gene expression and immunoreactivity are elevated in human glioblastoma multiforme. Cancer Res. 1994, 54, 2794-2799. [PubMed]

92. Pollard, S.M.; Yoshikawa, K.; Clarke, I.D.; Danovi, D.; Stricker, S.; Russell, R.; Bayani, J.; Head, R.; Lee, M.; Bernstein, M.; et al Glioma stem cell lines expanded in adherent culture have tumor-specific phenotypes and are suitable for chemical and genetic screens. Cell Stem Cell 2009, 4, 568-580. [CrossRef] [PubMed]

93. Lokker, N.A.; Sullivan, C.M.; Hollenbach, S.J.; Israel, M.A.; Giese, N.A. Platelet-derived growth factor (PDGF) autocrine signaling regulates survival and mitogenic pathways in glioblastoma cells: Evidence that the novel PDGF-C and PDGF-D ligands may play a role in the development of brain tumors. Cancer Res. 2002, 62, 3729-3735. 
94. Abounader, R.; Laterra, J. Scatter factor/hepatocyte growth factor in brain tumor growth and angiogenesis. Neuro Oncol. 2005, 7, 436-451. [CrossRef] [PubMed]

95. Koul, D. PTEN signaling pathways in glioblastoma. Cancer Biol Ther. 2008, 7, 1321-1325. [CrossRef]

96. Xie, S.; Ni, J.; McFaline-Figueroa, J.R.; Wang, Y.; Bronson, R.T.; Ligon, K.L.; Wen, P.Y.; Roberts, T.M.; Zhao, J.J. Divergent Roles of PI3K Isoforms in PTEN-Deficient Glioblastomas. Cell Rep. 2020, 32, 108196. [CrossRef] [PubMed]

97. Geribaldi-Doldan, N.; Gomez-Oliva, R.; Dominguez-Garcia, S.; Nunez-Abades, P.; Castro, C. Protein Kinase C: Targets to Regenerate Brain Injuries? Front. Cell Dev. Biol. 2019, 7, 39. [CrossRef]

98. Watanabe, T.; Ono, Y.; Taniyama, Y.; Hazama, K.; Igarashi, K.; Ogita, K.; Kikkawa, U.; Nishizuka, Y. Cell division arrest induced by phorbol ester in CHO cells overexpressing protein kinase C-delta subspecies. Proc. Natl. Acad. Sci. USA 1992, 89, 10159-10163. [CrossRef]

99. Dempsey, E.C.; Newton, A.C.; Mochly-Rosen, D.; Fields, A.P.; Reyland, M.E.; Insel, P.A.; Messing, R.O. Protein kinase C isozymes and the regulation of diverse cell responses. Am. J. Physiol. Lung Cell. Mol. Physiol. 2000, 279, L429-L438. [CrossRef]

100. Black, A.R.; Black, J.D. Protein kinase C signaling and cell cycle regulation. Front. Immunol. 2012, 3, 423. [CrossRef]

101. Mellor, H.; Parker, P.J. The extended protein kinase C superfamily. Biochem. J. 1998, 332 Pt 2, 281-292. [CrossRef]

102. Rosse, C.; Linch, M.; Kermorgant, S.; Cameron, A.J.; Boeckeler, K.; Parker, P.J. PKC and the control of localized signal dynamics. Nat. Rev. Mol. Cell Biol. 2010, 11, 103-112. [CrossRef] [PubMed]

103. Bell, R.M.; Burns, D.J. Lipid activation of protein kinase C. J. Biol. Chem. 1991, 266, 4661-4664. [CrossRef]

104. Ron, D.; Kazanietz, M.G. New insights into the regulation of protein kinase C and novel phorbol ester receptors. FASEB J. 1999, 13, 1658-1676. [CrossRef]

105. Newton, A.C. Protein kinase C: Structural and spatial regulation by phosphorylation, cofactors, and macromolecular interactions. Chem Rev. 2001, 101, 2353-2364. [CrossRef] [PubMed]

106. Ohno, S.; Nishizuka, Y. Protein kinase C isotypes and their specific functions: Prologue. J. Biochem. 2002, 132, 509-511. [CrossRef] [PubMed]

107. Newton, A.C. Protein kinase C: Perfectly balanced. Crit. Rev. Biochem. Mol. Biol. 2018, 53, 208-230. [CrossRef]

108. Szallasi, Z.; Blumberg, P.M. Prostratin, a nonpromoting phorbol ester, inhibits induction by phorbol 12-myristate 13-acetate of ornithine decarboxylase, edema, and hyperplasia in CD-1 mouse skin. Cancer Res. 1991, 51, 5355-5360.

109. Geribaldi-Doldan, N.; Flores-Giubi, E.; Murillo-Carretero, M.; Garcia-Bernal, F.; Carrasco, M.; Macias-Sanchez, A.J.; DominguezRiscart, J.; Verastegui, C.; Hernandez-Galan, R.; Castro, C. 12-Deoxyphorbols Promote Adult Neurogenesis by Inducing Neural Progenitor Cell Proliferation via PKC Activation. Int J. Neuropsychopharmacol. 2015, 19, pyv085. [CrossRef]

110. Murillo-Carretero, M.; Geribaldi-Doldan, N.; Flores-Giubi, E.; Garcia-Bernal, F.; Navarro-Quiroz, E.A.; Carrasco, M.; MaciasSanchez, A.J.; Herrero-Foncubierta, P.; Delgado-Ariza, A.; Verastegui, C.; et al. ELAC (3,12-di-O-acetyl-8-O-tigloilingol), a plant-derived lathyrane diterpene, induces subventricular zone neural progenitor cell proliferation through PKCbeta activation. Br. J. Pharm. 2017, 174, 2373-2392. [CrossRef] [PubMed]

111. Cullen, J.K.; Boyle, G.M.; Yap, P.Y.; Elmlinger, S.; Simmons, J.L.; Broit, N.; Johns, J.; Ferguson, B.; Maslovskaya, L.A.; Savchenko, A.I.; et al. Activation of PKC supports the anticancer activity of tigilanol tiglate and related epoxytiglianes. Sci. Rep. 2021, 11, 207. [CrossRef]

112. Flores-Giubi, E.; Geribaldi-Doldan, N.; Murillo-Carretero, M.; Castro, C.; Duran-Patron, R.; Macias-Sanchez, A.J.; HernandezGalan, R. Lathyrane, Premyrsinane, and Related Diterpenes from Euphorbia boetica: Effect on in Vitro Neural Progenitor Cell Proliferation. J. Nat. Prod. 2019, 82, 2517-2528. [CrossRef]

113. Dominguez-Garcia, S.; Gomez-Oliva, R.; Geribaldi-Doldan, N.; Hierro-Bujalance, C.; Sendra, M.; Ruiz, F.A.; Carrascal, L.; Macias-Sanchez, A.J.; Verastegui, C.; Hernandez-Galan, R.; et al. Effects of classical PKC activation on hippocampal neurogenesis and cognitive performance: Mechanism of action. Neuropsychopharmacology 2020. [CrossRef] [PubMed]

114. Dominguez-Garcia, S.; Geribaldi-Doldan, N.; Gomez-Oliva, R.; Ruiz, F.A.; Carrascal, L.; Bolivar, J.; Verastegui, C.; Garcia-Alloza, M.; Macias-Sanchez, A.J.; Hernandez-Galan, R.; et al. A novel PKC activating molecule promotes neuroblast differentiation and delivery of newborn neurons in brain injuries. Cell Death Dis. 2020, 11, 262. [CrossRef] [PubMed]

115. Garcia-Bernal, F.; Geribaldi-Doldan, N.; Dominguez-Garcia, S.; Carrasco, M.; Murillo-Carretero, M.; Delgado-Ariza, A.; DiezSalguero, M.; Verastegui, C.; Castro, C. Protein Kinase C Inhibition Mediates Neuroblast Enrichment in Mechanical Brain Injuries. Front. Cell. Neurosci. 2018, 12, 462. [CrossRef]

116. Dang, M.; Armbruster, N.; Miller, M.A.; Cermeno, E.; Hartmann, M.; Bell, G.W.; Root, D.E.; Lauffenburger, D.A.; Lodish, H.F.; Herrlich, A. Regulated ADAM17-dependent EGF family ligand release by substrate-selecting signaling pathways. Proc. Natl. Acad. Sci. USA 2013, 110, 9776-9781. [CrossRef] [PubMed]

117. Dang, M.; Dubbin, K.; D'Aiello, A.; Hartmann, M.; Lodish, H.; Herrlich, A. Epidermal growth factor (EGF) ligand release by substrate-specific a disintegrin and metalloproteases (ADAMs) involves different protein kinase C (PKC) isoenzymes depending on the stimulus. J. Biol. Chem. 2011, 286, 17704-17713. [CrossRef]

118. do Carmo, A.; Balca-Silva, J.; Matias, D.; Lopes, M.C. PKC signaling in glioblastoma. Cancer Biol. Ther. 2013, 14, 287-294. [CrossRef] [PubMed]

119. Fan, Q.W.; Cheng, C.; Knight, Z.A.; Haas-Kogan, D.; Stokoe, D.; James, C.D.; McCormick, F.; Shokat, K.M.; Weiss, W.A. EGFR signals to mTOR through PKC and independently of Akt in glioma. Sci. Signal. 2009, 2, ra4. [CrossRef] 
120. Wong, R.A.; Luo, X.; Lu, M.; An, Z.; Haas-Kogan, D.A.; Phillips, J.J.; Shokat, K.M.; Weiss, W.A.; Fan, Q.W. Cooperative Blockade of PKCalpha and JAK2 Drives Apoptosis in Glioblastoma. Cancer Res. 2020, 80, 709-718. [CrossRef]

121. Leirdal, M.; Sioud, M. Protein kinase Calpha isoform regulates the activation of the MAP kinase ERK1/2 in human glioma cells: Involvement in cell survival and gene expression. Mol. Cell Biol. Res. Commun. MCBRC 2000, 4, 106-110. [CrossRef]

122. Kohutek, Z.A.; diPierro, C.G.; Redpath, G.T.; Hussaini, I.M. ADAM-10-mediated N-cadherin cleavage is protein kinase C-alpha dependent and promotes glioblastoma cell migration. J. Neurosci. Off. J. Soc. Neurosci. 2009, 29, 4605-4615. [CrossRef]

123. Valdes-Rives, S.A.; de la Fuente-Granada, M.; Velasco-Velazquez, M.A.; Gonzalez-Flores, O.; Gonzalez-Arenas, A. LPA1 receptor activation induces PKCalpha nuclear translocation in glioblastoma cells. Int. J. Biochem. Cell Biol. 2019, 110, 91-102. [CrossRef]

124. Yoshiji, H.; Kuriyama, S.; Ways, D.K.; Yoshii, J.; Miyamoto, Y.; Kawata, M.; Ikenaka, Y.; Tsujinoue, H.; Nakatani, T.; Shibuya, M.; et al. Protein kinase $C$ lies on the signaling pathway for vascular endothelial growth factor-mediated tumor development and angiogenesis. Cancer Res. 1999, 59, 4413-4418. [PubMed]

125. Graff, J.R.; McNulty, A.M.; Hanna, K.R.; Konicek, B.W.; Lynch, R.L.; Bailey, S.N.; Banks, C.; Capen, A.; Goode, R.; Lewis, J.E.; et al. The protein kinase Cbeta-selective inhibitor, Enzastaurin (LY317615.HCl), suppresses signaling through the AKT pathway, induces apoptosis, and suppresses growth of human colon cancer and glioblastoma xenografts. Cancer Res. 2005, 65, 7462-7469. [CrossRef] [PubMed]

126. Wick, W.; Puduvalli, V.K.; Chamberlain, M.C.; van den Bent, M.J.; Carpentier, A.F.; Cher, L.M.; Mason, W.; Weller, M.; Hong, S.; Musib, L.; et al. Phase III study of enzastaurin compared with lomustine in the treatment of recurrent intracranial glioblastoma. J. Clin. Oncol. Off. J. Am. Soc. Clin. Oncol. 2010, 28, 1168-1174. [CrossRef]

127. Liu, Z.; Wei, Y.; Zhang, L.; Yee, P.P.; Johnson, M.; Zhang, X.; Gulley, M.; Atkinson, J.M.; Trebak, M.; Wang, H.G.; et al. Induction of store-operated calcium entry (SOCE) suppresses glioblastoma growth by inhibiting the Hippo pathway transcriptional coactivators YAP/TAZ. Oncogene 2019, 38, 120-139. [CrossRef] [PubMed]

128. Masliantsev, K.; Karayan-Tapon, L.; Guichet, P.O. Hippo Signaling Pathway in Gliomas. Cells 2021, 10, 184. [CrossRef] [PubMed]

129. Chen, Z.; Forman, L.W.; Williams, R.M.; Faller, D.V. Protein kinase C-delta inactivation inhibits the proliferation and survival of cancer stem cells in culture and in vivo. BMC Cancer 2014, 14, 90. [CrossRef] [PubMed]

130. Sarkar, S.; Yong, V.W. Reduction of protein kinase $C$ delta attenuates tenascin-C stimulated glioma invasion in three-dimensional matrix. Carcinogenesis 2010, 31, 311-317. [CrossRef] [PubMed]

131. Kim, M.J.; Kim, R.K.; Yoon, C.H.; An, S.; Hwang, S.G.; Suh, Y.; Park, M.J.; Chung, H.Y.; Kim, I.G.; Lee, S.J. Importance of PKCdelta signaling in fractionated-radiation-induced expansion of glioma-initiating cells and resistance to cancer treatment. J. Cell Sci. 2011, 124, 3084-3094. [CrossRef]

132. Lu, J.; Xu, Z.; Duan, H.; Ji, H.; Zhen, Z.; Li, B.; Wang, H.; Tang, H.; Zhou, J.; Guo, T.; et al. Tumor-associated macrophage interleukin-beta promotes glycerol-3-phosphate dehydrogenase activation, glycolysis and tumorigenesis in glioma cells. Cancer Sci. 2020, 111, 1979-1990. [CrossRef] [PubMed]

133. Sharif, T.R.; Sharif, M. Overexpression of protein kinase $C$ epsilon in astroglial brain tumor derived cell lines and primary tumor samples. Int. J. Oncol. 1999, 15, 237-243. [CrossRef] [PubMed]

134. Okhrimenko, H.; Lu, W.; Xiang, C.; Hamburger, N.; Kazimirsky, G.; Brodie, C. Protein kinase C-epsilon regulates the apoptosis and survival of glioma cells. Cancer Res. 2005, 65, 7301-7309. [CrossRef] [PubMed]

135. Toton, E.; Romaniuk, A.; Konieczna, N.; Hofmann, J.; Barciszewski, J.; Rybczynska, M. Impact of PKCepsilon downregulation on autophagy in glioblastoma cells. BMC Cancer 2018, 18, 185. [CrossRef]

136. Besson, A.; Davy, A.; Robbins, S.M.; Yong, V.W. Differential activation of ERKs to focal adhesions by PKC epsilon is required for PMA-induced adhesion and migration of human glioma cells. Oncogene 2001, 20, 7398-7407. [CrossRef]

137. Besson, A.; Wilson, T.L.; Yong, V.W. The anchoring protein RACK1 links protein kinase Cepsilon to integrin beta chains. Requirements for adhesion and motility. J. Biol. Chem. 2002, 277, 22073-22084. [CrossRef]

138. Fortin, S.; Le Mercier, M.; Camby, I.; Spiegl-Kreinecker, S.; Berger, W.; Lefranc, F.; Kiss, R. Galectin-1 is implicated in the protein kinase C epsilon/vimentin-controlled trafficking of integrin-beta1 in glioblastoma cells. Brain Pathol. 2010, 20, 39-49. [CrossRef]

139. Pal, D.; Basu, A. The unique protein kinase Ceta: Implications for breast cancer (review). Int. J. Oncol. 2014, 45, 493-498. [CrossRef]

140. Kashiwagi, M.; Ohba, M.; Chida, K.; Kuroki, T. Protein kinase C eta (PKC eta): Its involvement in keratinocyte differentiation. J. Biochem. 2002, 132, 853-857. [CrossRef]

141. Maddika, S.; Ande, S.R.; Panigrahi, S.; Paranjothy, T.; Weglarczyk, K.; Zuse, A.; Eshraghi, M.; Manda, K.D.; Wiechec, E.; Los, M. Cell survival, cell death and cell cycle pathways are interconnected: Implications for cancer therapy. Drug Resist. Updates Rev. Comment. Antimicrob. Anticancer Chemother. 2007, 10, 13-29. [CrossRef]

142. Aeder, S.E.; Martin, P.M.; Soh, J.W.; Hussaini, I.M. PKC-eta mediates glioblastoma cell proliferation through the Akt and mTOR signaling pathways. Oncogene 2004, 23, 9062-9069. [CrossRef]

143. Uht, R.M.; Amos, S.; Martin, P.M.; Riggan, A.E.; Hussaini, I.M. The protein kinase C-eta isoform induces proliferation in glioblastoma cell lines through an ERK/Elk-1 pathway. Oncogene 2007, 26, 2885-2893. [CrossRef]

144. Hussaini, I.M.; Carpenter, J.E.; Redpath, G.T.; Sando, J.J.; Shaffrey, M.E.; Vandenberg, S.R. Protein kinase C-eta regulates resistance to UV- and gamma-irradiation-induced apoptosis in glioblastoma cells by preventing caspase-9 activation. Neuro Oncol. 2002, 4, 9-21. [CrossRef] [PubMed] 
145. Baldwin, R.M.; Parolin, D.A.; Lorimer, I.A. Regulation of glioblastoma cell invasion by PKC iota and RhoB. Oncogene 2008, 27, 3587-3595. [CrossRef] [PubMed]

146. Desai, S.; Pillai, P.; Win-Piazza, H.; Acevedo-Duncan, M. PKC-iota promotes glioblastoma cell survival by phosphorylating and inhibiting BAD through a phosphatidylinositol 3-kinase pathway. Biochim. Biophys. Acta 2011, 1813, 1190-1197. [CrossRef] [PubMed]

147. Dey, A.; Islam, S.M.A.; Patel, R.; Acevedo-Duncan, M. The interruption of atypical PKC signaling and Temozolomide combination therapy against glioblastoma. Cell Signal. 2021, 77, 109819. [CrossRef] [PubMed]

148. Ma, L.; Tao, Y.; Duran, A.; Llado, V.; Galvez, A.; Barger, J.F.; Castilla, E.A.; Chen, J.; Yajima, T.; Porollo, A.; et al. Control of nutrient stress-induced metabolic reprogramming by PKCzeta in tumorigenesis. Cell 2013, 152, 599-611. [CrossRef] [PubMed]

149. Elsherbiny, M.E.; Chen, H.; Emara, M.; Godbout, R. Omega-3 and omega-6 Fatty Acids Modulate Conventional and Atypical Protein Kinase C Activities in a Brain Fatty Acid Binding Protein Dependent Manner in Glioblastoma Multiforme. Nutrients 2018, 10, 454. [CrossRef]

150. Guo, H.; Gu, F.; Li, W.; Zhang, B.; Niu, R.; Fu, L.; Zhang, N.; Ma, Y. Reduction of protein kinase C zeta inhibits migration and invasion of human glioblastoma cells. J. Neurochem. 2009, 109, 203-213. [CrossRef] [PubMed]

151. Esteve, P.O.; Chicoine, E.; Robledo, O.; Aoudjit, F.; Descoteaux, A.; Potworowski, E.F.; St-Pierre, Y. Protein kinase C-zeta regulates transcription of the matrix metalloproteinase-9 gene induced by IL-1 and TNF-alpha in glioma cells via NF-kappa B. J. Biol. Chem. 2002, 277, 35150-35155. [CrossRef]

152. Zhang, J.; Stevens, M.F.; Bradshaw, T.D. Temozolomide: Mechanisms of action, repair and resistance. Curr. Mol. Pharm. 2012, 5, 102-114. [CrossRef] [PubMed]

153. Stupp, R.; Mason, W.P.; van den Bent, M.J.; Weller, M.; Fisher, B.; Taphoorn, M.J.; Belanger, K.; Brandes, A.A.; Marosi, C.; Bogdahn, U.; et al. Radiotherapy plus concomitant and adjuvant temozolomide for glioblastoma. N. Engl. J. Med. 2005, 352, 987-996. [CrossRef] [PubMed]

154. Lau, D.; Magill, S.T.; Aghi, M.K. Molecularly targeted therapies for recurrent glioblastoma: Current and future targets. Neurosurg. Focus 2014, 37, E15. [CrossRef] [PubMed]

155. Touat, M.; Idbaih, A.; Sanson, M.; Ligon, K.L. Glioblastoma targeted therapy: Updated approaches from recent biological insights. Ann. Oncol. 2017, 28, 1457-1472. [CrossRef] [PubMed]

156. Finch, A.; Solomou, G.; Wykes, V.; Pohl, U.; Bardella, C.; Watts, C. Advances in Research of Adult Gliomas. Int. J. Mol. Sci 2021, 22, 924. [CrossRef] [PubMed]

157. Gundimeda, U.; Chen, Z.H.; Gopalakrishna, R. Tamoxifen modulates protein kinase C via oxidative stress in estrogen receptornegative breast cancer cells. J. Biol. Chem. 1996, 271, 13504-13514. [CrossRef]

158. Millward, M.J.; Cantwell, B.M.; Lien, E.A.; Carmichael, J.; Harris, A.L. Intermittent high-dose tamoxifen as a potential modifier of multidrug resistance. Eur. J. Cancer 1992, 28, 805-810. [CrossRef]

159. Pollack, I.F.; Randall, M.S.; Kristofik, M.P.; Kelly, R.H.; Selker, R.G.; Vertosick, F.T., Jr. Effect of tamoxifen on DNA synthesis and proliferation of human malignant glioma lines in vitro. Cancer Res. 1990, 50, 7134-7138.

160. Couldwell, W.T.; Hinton, D.R.; Surnock, A.A.; DeGiorgio, C.M.; Weiner, L.P.; Apuzzo, M.L.; Masri, L.; Law, R.E.; Weiss, M.H. Treatment of recurrent malignant gliomas with chronic oral high-dose tamoxifen. Clin. Cancer Res. 1996, $2,619-622$.

161. Robins, H.I.; Won, M.; Seiferheld, W.F.; Schultz, C.J.; Choucair, A.K.; Brachman, D.G.; Demas, W.F.; Mehta, M.P. Phase 2 trial of radiation plus high-dose tamoxifen for glioblastoma multiforme: RTOG protocol BR-0021. Neuro Oncol. 2006, 8, 47-52. [CrossRef]

162. Cristofori, A.; Carrabba, G.; Lanfranchi, G.; Menghetti, C.; Rampini, P.; Caroli, M. Continuous tamoxifen and dose-dense temozolomide in recurrent glioblastoma. Anticancer Res. 2013, 33, 3383-3389.

163. Gao, J.; Aksoy, B.A.; Dogrusoz, U.; Dresdner, G.; Gross, B.; Sumer, S.O.; Sun, Y.; Jacobsen, A.; Sinha, R.; Larsson, E.; et al Integrative analysis of complex cancer genomics and clinical profiles using the cBioPortal. Sci. Signal. 2013, 6, pl1. [CrossRef] [PubMed]

164. Brandes, A.A.; Ermani, M.; Turazzi, S.; Scelzi, E.; Berti, F.; Amista, P.; Rotilio, A.; Licata, C.; Fiorentino, M.V. Procarbazine and high-dose tamoxifen as a second-line regimen in recurrent high-grade gliomas: A phase II study. J. Clin. Oncol. Off. J. Am. Soc. Clin. Oncol. 1999, 17, 645-650. [CrossRef] [PubMed]

165. Spence, A.M.; Peterson, R.A.; Scharnhorst, J.D.; Silbergeld, D.L.; Rostomily, R.C. Phase II study of concurrent continuous Temozolomide (TMZ) and Tamoxifen (TMX) for recurrent malignant astrocytic gliomas. J. Neuro Oncol. 2004, 70, 91-95. [CrossRef]

166. Kreisl, T.N.; Kim, L.; Moore, K.; Duic, P.; Kotliarova, S.; Walling, J.; Musib, L.; Thornton, D.; Albert, P.S.; Fine, H.A. A phase I trial of enzastaurin in patients with recurrent gliomas. Clin. Cancer Res. 2009, 15, 3617-3623. [CrossRef] [PubMed]

167. Kreisl, T.N.; Kotliarova, S.; Butman, J.A.; Albert, P.S.; Kim, L.; Musib, L.; Thornton, D.; Fine, H.A. A phase I/II trial of enzastaurin in patients with recurrent high-grade gliomas. Neuro Oncol. 2010, 12, 181-189. [CrossRef]

168. Rampling, R.; Sanson, M.; Gorlia, T.; Lacombe, D.; Lai, C.; Gharib, M.; Taal, W.; Stoffregen, C.; Decker, R.; van den Bent, M.J. A phase I study of LY317615 (enzastaurin) and temozolomide in patients with gliomas (EORTC trial 26054). Neuro Oncol. 2012, 14, 344-350. [CrossRef] [PubMed]

169. Butowski, N.; Chang, S.M.; Lamborn, K.R.; Polley, M.Y.; Parvataneni, R.; Hristova-Kazmierski, M.; Musib, L.; Nicol, S.J.; Thornton, D.E.; Prados, M.D. Enzastaurin plus temozolomide with radiation therapy in glioblastoma multiforme: A phase I study. Neuro Oncol. 2010, 12, 608-613. [CrossRef] [PubMed] 
170. Odia, Y.; Iwamoto, F.M.; Moustakas, A.; Fraum, T.J.; Salgado, C.A.; Li, A.; Kreisl, T.N.; Sul, J.; Butman, J.A.; Fine, H.A. A phase II trial of enzastaurin (LY317615) in combination with bevacizumab in adults with recurrent malignant gliomas. J. Neuro Oncol. 2016, 127, 127-135. [CrossRef] [PubMed]

171. Grossman, S.A.; Alavi, J.B.; Supko, J.G.; Carson, K.A.; Priet, R.; Dorr, F.A.; Grundy, J.S.; Holmlund, J.T. Efficacy and toxicity of the antisense oligonucleotide aprinocarsen directed against protein kinase $\mathrm{C}$-alpha delivered as a 21-day continuous intravenous infusion in patients with recurrent high-grade astrocytomas. Neuro Oncol. 2005, 7, 32-40. [CrossRef]

172. Teicher, B.A.; Alvarez, E.; Menon, K.; Esterman, M.A.; Considine, E.; Shih, C.; Faul, M.M. Antiangiogenic effects of a protein kinase Cbeta-selective small molecule. Cancer Chemother. Pharm. 2002, 49, 69-77. [CrossRef] [PubMed]

173. Teicher, B.A.; Menon, K.; Alvarez, E.; Shih, C.; Faul, M.M. Antiangiogenic and antitumor effects of a protein kinase Cbeta inhibitor in human breast cancer and ovarian cancer xenografts. Investig. New Drugs 2002, 20, 241-251. [CrossRef]

174. Ma, S.; Rosen, S.T. Enzastaurin. Curr. Opin. Oncol. 2007, 19, 590-595. [CrossRef] [PubMed]

175. Pearson, J.R.D.; Regad, T. Targeting cellular pathways in glioblastoma multiforme. Signal. Transduct. Target. Ther. 2017, 2, 17040. [CrossRef] [PubMed]

176. Schlessinger, J. Cell signaling by receptor tyrosine kinases. Cell 2000, 103, 211-225. [CrossRef]

177. Oprita, A.; Baloi, S.C.; Staicu, G.A.; Alexandru, O.; Tache, D.E.; Danoiu, S.; Micu, E.S.; Sevastre, A.S. Updated Insights on EGFR Signaling Pathways in Glioma. Int. J. Mol. Sci. 2021, 22, 587. [CrossRef]

178. Huang, H.S.; Nagane, M.; Klingbeil, C.K.; Lin, H.; Nishikawa, R.; Ji, X.D.; Huang, C.M.; Gill, G.N.; Wiley, H.S.; Cavenee, W.K. The enhanced tumorigenic activity of a mutant epidermal growth factor receptor common in human cancers is mediated by threshold levels of constitutive tyrosine phosphorylation and unattenuated signaling. J. Biol. Chem. 1997, 272, $2927-2935$. [CrossRef] [PubMed]

179. Pitz, M.W.; Eisenhauer, E.A.; MacNeil, M.V.; Thiessen, B.; Easaw, J.C.; Macdonald, D.R.; Eisenstat, D.D.; Kakumanu, A.S.; Salim, M.; Chalchal, H.; et al. Phase II study of PX-866 in recurrent glioblastoma. Neuro Oncol. 2015, 17, 1270-1274. [CrossRef]

180. Wen, N.; Guo, B.; Zheng, H.; Xu, L.; Liang, H.; Wang, Q.; Wang, D.; Chen, X.; Zhang, S.; Li, Y.; et al. Bromodomain inhibitor jq1 induces cell cycle arrest and apoptosis of glioma stem cells through the VEGF/PI3K/AKT signaling pathway. Int. J. Oncol. 2019, 55, 879-895. [CrossRef]

181. Kamezaki, A.; Sato, F.; Aoki, K.; Asakawa, K.; Kawakami, K.; Matsuzaki, F.; Sehara-Fujisawa, A. Visualization of Neuregulin 1 ectodomain shedding reveals its local processing in vitro and in vivo. Sci. Rep. 2016, 6, 28873. [CrossRef] 